\title{
A detailed analysis of innate and adaptive immune responsiveness upon infection with Salmonella enterica serotype Enteritidis in young broiler chickens
}

Nathalie Meijerink', Robin H. G. A. van den Biggelaar ${ }^{1}$, Daphne A. van Haarlem', J. Arjan Stegeman², Victor P. M. G. Rutten ${ }^{1,3}$ and Christine A. Jansen ${ }^{1,4^{*}}$ (i)

\begin{abstract}
Salmonella enterica serotype Enteritidis (SE) is a zoonotic pathogen which causes foodborne diseases in humans as well as severe disease symptoms in young chickens. More insight in innate and adaptive immune responses of chickens to SE infection is needed to understand elimination of SE. Seven-day-old broiler chickens were experimentally challenged with SE and numbers and responsiveness of innate and adaptive immune cells as well as antibody titers were assessed. SE was observed in the ileum and spleen of SE-infected chickens at 7 days post-infection (dpi). At 1 dpi numbers of intraepithelial cytotoxic $\mathrm{CD}^{+} \mathrm{T}$ cells were significantly increased alongside numerically increased intraepithelial IL-2Ra ${ }^{+}$and $20 \mathrm{E} 5^{+}$natural killer (NK) cells at 1 and 3 dpi. At both time points, activation of intraepithelial and splenic NK cells was significantly enhanced. At $7 \mathrm{dpi}$ in the spleen, presence of macrophages and expression of activation markers on dendritic cells were significantly increased. At $21 \mathrm{dpi}$, SE-induced proliferation of splenic $\mathrm{CD}^{+}$and $\mathrm{CD} 8^{+} \mathrm{T}$ cells was observed and SE-specific antibodies were detected in sera of all SE-infected chickens. In conclusion, SE results in enhanced numbers and activation of innate cells and we hypothesized that in concert with subsequent specific $T$ cell and antibody responses, reduction of SE is achieved. A better understanding of innate and adaptive immune responses important in the elimination of SE will aid in developing immune-modulation strategies, which may increase resistance to SE in young broiler chickens.
\end{abstract}

Keywords: Broiler chickens, Salmonella enterica serotype Enteritidis, Innate, Adaptive, Immunity, NK cells, Antigenpresenting cells, T cells, IELs

\section{Introduction}

Salmonella enterica serotype Enteritidis (SE) is one of the leading causes of foodborne diseases in humans, most often due to poultry products that are not well prepared. In chickens infected with faecal Salmonellae via oral or

\footnotetext{
*Correspondence: c.a.jansen@uu.nl

${ }^{1}$ Department Biomolecular Health Sciences, Division Infectious Diseases and Immunology, Faculty of Veterinary Medicine, Utrecht University, Utrecht, The Netherlands

Full list of author information is available at the end of the article
}

respiratory routes, SE colonizes the intestinal tract and disseminates systemically to tissues such as the liver and spleen $[1,2]$. In young chickens it can lead to severe disease and death, whereas adult chickens are often subclinically infected with SE, carrying the bacteria in their intestines [3]. Prevention of SE infection in poultry is thus important for health and welfare of young chickens and to avoid substantial economic production losses in the poultry sector as a consequence. In addition, SE prevention in poultry is significant for the health and wellbeing of humans as well as to avoid loss of productivity original author(s) and the source, provide a link to the Creative Commons licence, and indicate if changes were made. The images or other third party material in this article are included in the article's Creative Commons licence, unless indicated otherwise in a credit line to the material. If material is not included in the article's Creative Commons licence and your intended use is not permitted by statutory regulation or exceeds the permitted use, you will need to obtain permission directly from the copyright holder. To view a copy of this licence, visit http://creativecommons.org/licenses/by/4.0/. The Creative Commons Public Domain Dedication waiver (http://creativeco mmons.org/publicdomain/zero/1.0/) applies to the data made available in this article, unless otherwise stated in a credit line to the data. 
and health care costs. Since therapeutic treatment of SE infection in chickens with antibiotics is not advised due to limited effectiveness and risk of antibiotic resistance, the use of immune-modulatory strategies to increase the resistance to $\mathrm{SE}$ is encouraged [4]. More insight in innate and adaptive immune responses and their interaction in response to SE infection in young broiler chickens will facilitate the design of these strategies.

In young chickens, immunity largely depends on maternal antibodies as well activity of the innate immune system, with natural killer (NK) cells and macrophages as key players $[5,6]$. Due to the low numbers of NK cells that can be isolated from the caecum $[7,8]$ and since the ileum is generally considered as a site of immune activation with many lymphoid structures $[9,10]$, we set out to study immune responses induced by SE in the ileum. NK cells are particularly abundant amongst intestinal intraepithelial lymphocytes (IELs) [11, 12], which are also rich in $\gamma \delta \mathrm{T}$ cells and CD8 ${ }^{+} \mathrm{T}$ cells expressing the $\alpha \beta \mathrm{T}$ cell receptor (TCR) $[11,13]$. Macrophages, dendritic cells (DCs) and $\mathrm{CD}^{+}{ }^{+} \mathrm{T}$ cells are located directly underneath the intestinal epithelium [14]. The adaptive immune system is not fully developed yet upon hatch and functional $\mathrm{T}$ - and B-cell responses are observed after approximately 2 to 3 weeks of life $[5,6]$.

The early response of the innate immune system in chickens within 1 week post-SE infection is characterized by the upregulation of genes associated with "defense/ pathogen response" [15], inflammation [16-18], NK cellmediated cytotoxicity [19] and production and secretion of the cytokine IFNY [20]. Other studies have shown the influx of heterophils and macrophages in the spleen and $\gamma \delta \mathrm{T}$ cells in the caecum, and expression of activationrelated genes in the respective cell types during the first response to SE in chickens [21,22]. However, the effect of SE infection on the function of NK cells in chickens has not been studied so far. In chickens, intraepithelial NK cells comprise a major CD3 ${ }^{-} \mathrm{IL}-2 \mathrm{R}^{+}$subset $[11,12]$ and a minor $\mathrm{CD}^{-} 20 \mathrm{E}^{+}$subset [12], both having cytotoxic capacity but to different degrees. In mice and humans, high cytotoxic activity $[23,24]$ and IFN- $\gamma$ production $[24$, 25 ] by NK cells have been shown to result in resistance to Salmonella enterica serotype Typhimurium. This suggests an important role for NK cells as well in the first response to SE.

The development of $\mathrm{T}$ and $\mathrm{B}$ cell responses is initiated with the activation of professional antigen presenting cells (APCs) such as DCs and macrophages. The presence [26] and activity of intestinal macrophages [27-29], identified by the expression of mannose receptor $C$-type 1-like B (MRC1LB) [30], and bone marrow-derived DCs [31] increases during SE infection. Furthermore, oral infection of 1-day-old specific-pathogen-free chickens with SE elicits increased mRNA expression of chemokines and macrophages are attracted to the ileum within $24 \mathrm{~h}$ [32]. In addition, it has been shown that decreased activity of peritoneal macrophage is associated with increased susceptibility for systemic dissemination of SE in chickens [33]. On the other hand, Salmonella species have been found to resist killing by macrophages in mammals [34] and chickens [35, 36] and even use macrophages as a carrier for systemic dissemination [37]. Despite their involvement in SE infection, a detailed analysis of the effect of SE infection on the function of APCs in chickens has not been performed to date.

Initial $\mathrm{T}$ cell responsiveness to $\mathrm{SE}$ in chickens has been observed within 1 week, including increased presence of $\gamma \delta \mathrm{T}$ cells in the intestine, blood and spleen after vaccination with live-attenuated SE or SE infection as compared to SE negative chickens [20,22]. In addition, enhanced mRNA expression of cytotoxic activity-related genes was observed in the spleen of SE-infected compared to uninfected chickens [38]. Two and three weeks postvaccination or infection, a second increase in presence of $\gamma \delta \mathrm{T}$ cells was observed in the spleen and intestine, respectively, compared to non-immunized chickens [22]. $\mathrm{CD}^{+}$helper $\mathrm{T}$ cells and $\mathrm{CD}^{+}{ }^{+}$cytotoxic $\mathrm{T}$ cells were also shown to increase in presence within 1 week post$\mathrm{SE}$ infection and vaccination in the intestine, as compared to uninfected and non-vaccinated chickens [20, $26,27] . \mathrm{CD}^{+}$cytotoxic $\mathrm{T}$ cells kill infected host cells, while $\mathrm{CD} 4^{+}$helper $\mathrm{T}$ cells release cytokines like IL-2 and IFNY to further stimulate NK cells, and macrophages and $\mathrm{CD}^{+}$cytotoxic $\mathrm{T}$ cells respectively, and promote the differentiation of B cells into antibody-producing plasma cells. Antibody responses involved in elimination of SE partly depend on maternal antibodies and on the production of IgA in the intestine [39, 40], as well as IgM, IgA and IgY antibodies in blood [40,41]. Whereas previous studies have focussed on specific aspects of the immune responses, the present study combines cellular assays to analyze both the innate and adaptive immune responses in the IEL population and spleen upon SE infection in chickens.

In this study, we investigated how Salmonella enterica serotype Enteritidis infection in young broiler chickens affects presence and activation of innate and adaptive immune cells in the IEL population and spleen to obtain more insight in the contribution of the immune system to elimination of the infection. Numbers of SE in ileum and spleen were determined alongside differences in kinetics of presence and activation status of NK cell and APC subsets between uninfected and infected chickens. The subsequent adaptive responses were determined including presence and activation of $\gamma \delta \mathrm{T}$ cell, $\mathrm{CD} 4^{+}$and $\mathrm{CD}^{+} \mathrm{T}$ cell subsets, and serum antibody levels. Hence 
the present study provides an extensive overview of intraepithelial and systemic immune responses that are evoked by SE infection in young broiler chickens. Based on the phenotypical and functional data obtained, we will hypothesize on how the various elements of the immune system interact and contribute to elimination of the SE infection, and on potential strengthening of immune responsiveness by immunomodulation strategies, which may prevent SE infection and colonization, and thus increase chicken health and welfare as well as safety of food of chicken origin.

\section{Materials and methods}

\section{Animals and husbandry}

A total of 30 respectively 35 Ross 30817 - and 18-day old embryonated eggs were obtained from the same parent flock of a commercial hatchery (Lagerwey, the Netherlands). Eggs were disinfected with 3\% hydrogen peroxide and placed in disinfected hatchers in two different stables (ED17 eggs: uninfected chickens and ED18 eggs: SE-infected chickens) at the facilities of the Department of Population Health Sciences, Faculty of Veterinary Medicine, Utrecht University, the Netherlands. Cleaning the eggs with a low concentration of hydrogen peroxide is a standard procedure. It is highly unlikely that it influences intestinal microbiota composition as described in a previous study [42]. Directly upon hatch, chickens were weighed, labelled and female and male chickens were equally distributed in floor pens of $2 \times 2 \mathrm{~m}$ lined with wood shavings $\left(2 \mathrm{~kg} / \mathrm{m}^{2}\right)$, and received water and standard Salmonella-free commercial starter and grower feeds ad libitum (Research Diet Services, the Netherlands). A standard lighting and temperature scheme for Ross broiler chickens was used for both stables.

The animal experiment was approved by the Dutch Central Authority for Scientific Procedures on Animals and the Animal Experiments Committee (registration number AVD1080020174425) of Utrecht University (the Netherlands) and all procedures were done in full compliance with all relevant legislation.

\section{Experimental design}

Before the start of the experiment at day 3, five chickens per group [uninfected $(n=30)$ and SE-infected $(n=35)$ ] were randomly selected and sacrificed for collection of ileum $( \pm 10 \mathrm{~cm}$ distal from Meckel's diverticulum) and spleen to confirm absence of SE before inoculation. At day 7 [0 days post-infection (dpi)], five chickens of the SE-infected group only, were randomly selected and sacrificed for collection of ileum and spleen, to determine baseline levels of the various immune parameters as well as absence of SE before infection. Subsequently, chickens of the SE-infected group were challenged at day 7 ( 0 dpi) by oral inoculation of $0.25 \mathrm{~mL}$ brain heart infusion (BHI) medium containing $1.12 \times 10^{6}$ colony-forming units (CFUs) SE, whereas chickens in the other stable (uninfected) were inoculated with $0.25 \mathrm{~mL} \mathrm{BHI}$ medium. At days 8 (1 dpi), 10 (3 dpi), 14 (7 dpi), 21 (14 dpi) and 28 (21 dpi), five chickens per group were randomly selected and sacrificed for collection of ileum and spleen to determine bacterial CFUs as well as numbers and function of NK cells and T cells. At days 7, 8, 10 and 14 also spleen APCs were assessed. At days 7, 14, 21 and 28 blood (at least $5 \mathrm{~mL}$ ) was collected in EDTA tubes (VACUETTE ${ }^{\circledR}$ K3E EDTA, Greiner Bio-One, the Netherlands) for determination of SE-specific antibody levels. At day 28, splenic lymphocytes were also used to assess SE-induced T cell reactivity in a proliferation assay. The use of five chickens per group per time point was calculated using power analysis (Sample size \& power calculator, LASEC, China). All chickens were weighed prior to post-mortem analyses to determine the growth curve. To calculate absolute cell numbers, ileum segments and spleens were weighed immediately after collection of the tissues, prior to isolation of cells. After isolation, cell numbers in the resulting suspension were calculated. This resulted in the total cell number, expressed as IELs per mg ileum or leukocytes per mg spleen. To calculate the absolute numbers of NK cells, APCs and T cells within the live IEL or leukocyte populations, the percentages of cells positive for the markers expressed on these cell types were used which were determined in the flow cytometry analyses. Absolute cell numbers were calculated using the following formula: (absolute number IELs or leukocytes per mg tissue) $\times$ (percentage positive cells in the gate of interest of the live lymphocyte or leukocyte population).

\section{SE culture}

The Salmonella enterica serotype Enteritidis strain $\left(\mathrm{K} 285 / 93 \mathrm{Nal}^{\mathrm{res}}\right)$ was kindly provided by Dr E. Broens, director of the Veterinary Microbiological Diagnostic Center (VMDC) of the Faculty of Veterinary Medicine, Utrecht University, and cultured as described previously [43]. In short, from an overnight culture of the SE strain on blood agar (Oxoid, the Netherlands) a single colony was used to inoculate $45 \mathrm{~mL}$ BHI medium (Oxoid), which was incubated aerobically overnight at $200 \mathrm{rpm}$ in a shaking incubator (Certomat BS-1, B. Braun Biotech international, Sweden) at $37^{\circ} \mathrm{C}$. The OD value of a sample of the SE culture diluted 1:10 in PBS was measured using a Ultrospec 2000 (Pharmacia Biotech, Sweden), the SE concentration was calculated from a previously determined growth curve, and SE were diluted in BHI medium to $4 \times 10^{6} \mathrm{CFU} / \mathrm{mL}$, to constitute the inoculum. The exact SE concentration of the inoculum, determined 
by counting the number of CFUs of plated serial dilutions after overnight culture, was $4.49 \times 10^{6} \mathrm{CFU} / \mathrm{mL}$.

For the $\mathrm{T}$ cell proliferation assay, SE was fixed by resuspending $3.8 \times 10^{9} \mathrm{CFUs}$ in $100 \mu \mathrm{L}$ PBS with $1 \%$ formaldehyde (Sigma-Aldrich, the Netherlands) and incubation for $5 \mathrm{~min}$ at RT, while the suspension was vortexed shortly every minute. After fixation, the bacteria were washed four times in $1 \mathrm{~mL}$ PBS by centrifugation at $15000 \times g$ to remove the supernatants (Heraeus Pico 17 Centrifuge, Thermo Fisher Scientific). Finally, the bacteria were resuspended in $380 \mu \mathrm{L}$ X-VIVO 15 cell culture medium (Lonza, the Netherlands) with $50 \mu \mathrm{g} / \mathrm{mL}$ gentamycin (Gibco ${ }^{\mathrm{TM}}$, the Netherlands) to create a concentration of $10^{7} \mathrm{CFU} / \mathrm{mL}$ and stored at $4{ }^{\circ} \mathrm{C}$ until further use.

\section{Isolation of cells}

The procedures to isolate IELs from ileum and leukocytes from spleen were performed as described previously [12, 44]. Ileum segments were washed with PBS to remove the contents, cut into sections of $1 \mathrm{~cm}^{2}$ and washed again. Subsequently, the IELs were collected by incubating three times in a shaking incubator (Certomat BS-1) at $200 \mathrm{rpm}$ for $15 \mathrm{~min}$ at $37^{\circ} \mathrm{C}$ in EDTA-medium [HBSS $1 \mathrm{x}\left(\mathrm{Gibco}^{\circledR}\right)$ supplemented with $10 \%$ heat-inactivated FCS (Lonza) and 1\% 0.5 M EDTA-Na (UltraPure $^{\mathrm{TM}}$, Invitrogen, the Netherlands)]. Supernatants were collected and centrifuged for $5 \mathrm{~min}$ at $335 \times g$ at $20{ }^{\circ} \mathrm{C}$ (Allegra $^{\mathrm{TM}}$ $\mathrm{X}-12 \mathrm{R}$ Centrifuge, Beckman Coulter, the Netherlands). Pellets were then resuspended in PBS at a concentration of $10 \mathrm{~mL}$ per gram tissue and an aliquot of $100 \mu \mathrm{L}$ was used for bacteriological analysis. PBS was added to the remaining suspension up to $20 \mathrm{~mL}$ and IELs were isolated using Ficoll-Paque Plus (GE Healthcare, the Netherlands) density gradient centrifugation for $12 \mathrm{~min}$ at $673 \times g$ at $20^{\circ} \mathrm{C}$, washed in PBS by centrifugation for $5 \mathrm{~min}$ at $393 \times g$ at $4{ }^{\circ} \mathrm{C}$ and resuspended at $4.0 \times 10^{6}$ cells $/ \mathrm{mL}$ in complete medium (IMDM $2 \mathrm{mM}$ glutamax I supplemented with $8 \%$ heat-inactivated FCS (Lonza), 2\% heat-inactivated chicken serum, $100 \mathrm{U} / \mathrm{mL}$ penicillin and $100 \mu \mathrm{g} / \mathrm{mL}$ streptomycin; Gibco $\left.{ }^{\circledR}\right)$. Spleens were homogenized using a $70 \mu \mathrm{m}$ cell strainer (Beckton Dickinson (BD) Biosciences, NJ, USA) and the single-cell suspension was diluted in PBS at a concentration of $10 \mathrm{~mL}$ per gram tissue. An aliquot of $100 \mu \mathrm{L}$ was used again for bacteriological analysis. Next, leukocytes were isolated by FicollPaque Plus density gradient centrifugation (20 min, 1126 $\times g, 20^{\circ} \mathrm{C}$ ), washed in PBS and resuspended at $4.0 \times 10^{6}$ cells $/ \mathrm{mL}$ in complete medium as described for ileum.

Whole blood was allowed to coagulate by leaving it undisturbed for $1 \mathrm{~h}$ at room temperature (RT), centrifuged for $10 \mathrm{~min}$ at $2095 \times g$ at $15{ }^{\circ} \mathrm{C}$ and subsequently, serum was collected and stored at $-20{ }^{\circ} \mathrm{C}$ until further use.

\section{Quantitative bacteriology of ileum and spleen}

At - 4, 0, 1, 3, 7, 14 and $21 \mathrm{dpi}$, the numbers of Salmonella colonies in ileum and spleen were determined by plating $100 \mu \mathrm{L}$ of the cell suspensions of either the ileum segments or homogenized spleens with a spatula on RAPID' Salmonella Medium plates (Bio-Rad, the Netherlands). Plates were incubated overnight at $37{ }^{\circ} \mathrm{C}$ and subsequently, purple colonies were quantified and SE was expressed as CFU per gram tissue. The limit of detection (LOD) was $100 \mathrm{CFU}$ per gram tissue.

\section{Phenotypic characterization of lymphocytes by flow cytometry}

Presence and activation of NK and T cell subsets were determined among IELs and splenocytes at $0,1,3,7$, 14 and $21 \mathrm{dpi}$ as described previously [12, 42]. Lymphocyte populations $\left(1 \times 10^{6}\right)$ were stained with a panel of antibodies specific for surface markers known to be expressed on NK cells, as well as with anti-CD3 to exclude $\mathrm{T}$ cells from the analyses. In addition, cells were stained with a panel of antibodies specific for surface markers that distinguishes $\gamma \delta \mathrm{T}$ cell, $\mathrm{CD}^{+}{ }^{+}$and $\mathrm{CD} 8^{+}$ $T$ cell subsets (Table 1 ). Staining with primary and secondary antibodies was performed in $50 \mu \mathrm{L}$ PBS (Lonza) containing $0.5 \%$ bovine serum albumin and $0.1 \%$ sodium azide (PBA). Cells were incubated for $20 \mathrm{~min}$ at $4{ }^{\circ} \mathrm{C}$ in the dark, washed twice by centrifugation for $5 \mathrm{~min}$ at $393 \times g$ at $4{ }^{\circ} \mathrm{C}$ in PBA, after primary staining, and in PBS after secondary staining. Subsequently, to be able to exclude dead cells from analysis, lymphocytes were stained in $100 \mu \mathrm{L}$ PBS with a viability dye (Zombie Aqua $^{\mathrm{TM}}$ Fixable Viability Kit, Biolegend, the Netherlands) for $15 \mathrm{~min}$ at RT in the dark, washed twice in PBA and resuspended in $200 \mu \mathrm{L}$ PBA. Of each sample, either 150 $\mu \mathrm{L}$ or a maximum of $1 \times 10^{6}$ viable cells were analyzed using a CytoFLEX LX Flow Cytometer (Beckman Coulter), and data was analyzed with FlowJo software (FlowJo LCC, BD Biosciences). The gating strategies used to analyze NK cells, $\gamma \delta \mathrm{T}$ cells and cytotoxic $\mathrm{CD} 8^{+} \mathrm{T}$ cells are depicted in Additional file 1.

\section{CD107 assay}

Activation of NK cells and cytotoxic $\mathrm{CD}^{+} \mathrm{T}$ cells was determined using the $\mathrm{CD} 107$ assay, which measures the increased surface expression of CD107a that results from degranulation, the release of cytotoxic granules [44]. Briefly, lymphocytes isolated from the IEL population and spleen were resuspended in complete medium, and $1 \times 10^{6}$ lymphocytes in $0.5 \mathrm{~mL}$ were incubated in the presence of $1 \mu \mathrm{L} / \mathrm{mL}$ GolgiStop (BD Biosciences) and 
Table 1 Flow cytometry staining reagents

\begin{tabular}{|c|c|c|c|}
\hline Cell population & $\begin{array}{l}\text { Primary antibody (mouse-anti- } \\
\text { chicken) }\end{array}$ & Clone/isotype & Secondary antibody \\
\hline \multirow[t]{4}{*}{ NK cells } & $\mathrm{CD}_{45}-\mathrm{FITC}^{1}$ & LT40/lgM & - \\
\hline & $\mathrm{CD}_{3}-\mathrm{APC}^{1}$ & CT3/lgG1 & - \\
\hline & IL-2Ra-UNL ${ }^{2}$ & $28-4 / \lg G 3$ & Goat-anti-mouse-lgG3-PE ${ }^{1}$ \\
\hline & 20E5-BIOT ${ }^{2}$ & $\operatorname{lgG1}$ & Streptavidin (SA)-Perc $\mathrm{P}^{6}$ \\
\hline \multirow[t]{5}{*}{ T cells } & CD3-PE ${ }^{1}$ & CT3/lgG1 & - \\
\hline & CD4-APC $^{1}$ & CT4/lgG1 & - \\
\hline & TCR $\gamma \delta-F I T C^{1}$ & TCR-1/lgG1 & - \\
\hline & CD8a-UNL ${ }^{1}$ & $\mathrm{EP} 72 / \lg \mathrm{g} 2 \mathrm{~b}$ & Goat-anti-mouse-lgG2b-APC/Cy $7^{1}$ \\
\hline & $\mathrm{CD} 8 \beta-\mathrm{BIOT}^{1}$ & $\mathrm{EP} 42 / \mathrm{lg} \mathrm{g} 2 \mathrm{a}$ & SA-PercP $P^{6}$ \\
\hline \multirow[t]{10}{*}{ APCs } & CD41/61-FITC ${ }^{4}$ & $11 \mathrm{C} 3 / \operatorname{lgG} 1$ & - \\
\hline & Bu-1-AF647' & AV20/lgG1 & - \\
\hline & CD3-FITC ${ }^{1}$ & $\mathrm{CT} 3 / \operatorname{lgG} 1$ & - \\
\hline & CD4-PE/Cy $7^{1}$ & CT4/lgG1 & - \\
\hline & MRC1LB-PE ${ }^{1}$ & KUL01/lgG1 & - \\
\hline & CD11-biotin ${ }^{2}$ & $5 C 7 / \operatorname{lgG} 1$ & SA-Brilliant Violet (BV) $605^{7}$ \\
\hline & MHC-II-UNL ${ }^{1}$ & $\mathrm{Cia} / \operatorname{lgM}$ & Rat-anti-mouse-IgM-BV421 (RMM-1) ${ }^{7}$ \\
\hline & ${ }^{*} \mathrm{CHIR}-\mathrm{AB} 1-\mathrm{UNL}{ }^{2}$ & $8 \mathrm{D} 12 / \lg 2 \mathrm{a}$ & Rat-anti-mouse-IgG2a-PerCP/Cy5.5 (RMG2a-62) \\
\hline & ${ }^{*} \mathrm{CD} 40-\mathrm{UNL}^{5}$ & AV79/lgG2a & Rat-anti-mouse-IgG2a-PerCP/Cy5.5 (RMG2a-62) \\
\hline & ${ }^{*} \mathrm{CD} 80-\mathrm{UNL}{ }^{5}$ & IAH:F864:DC7/lgG2a & Rat-anti-mouse-IgG2a-PerCP/Cy5.5 (RMG2a-62) \\
\hline \multicolumn{4}{|r|}{ 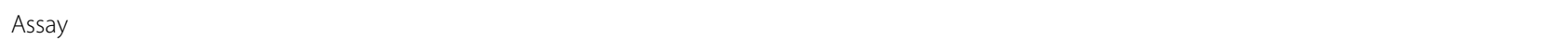 } \\
\hline \multirow[t]{6}{*}{ CD107 } & CD107a-APC ${ }^{3}$ & LEP-100 I 5G10/lgG1 & - \\
\hline & CD41/61-FITC ${ }^{4}$ & $11 C 3 / \operatorname{lgG} 1$ & - \\
\hline & CD3-PE & $\mathrm{CT} 3 / \lg \mathrm{g} 1$ & - \\
\hline & CD8a-UNL ${ }^{1}$ & $E P 72 / \lg 2 \mathrm{~b}$ & Goat-anti-mouse-lgG2b-Alexa Fluor (AF) $790^{8}$ \\
\hline & $28-4-U N L^{2}$ & $\operatorname{lgG} 3$ & Goat-anti-mouse-IgG3-APC/Cy $7^{1}$ \\
\hline & $20 \mathrm{E} 5-\mathrm{BIOT}^{2}$ & $\lg G 1$ & SA-PercP ${ }^{6}$ \\
\hline \multirow[t]{6}{*}{ IFNY } & CD3-PE ${ }^{1}$ & 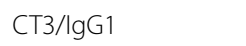 & - \\
\hline & TCRY $\delta$-FITC ${ }^{1}$ & $\mathrm{TCR}-1 / \operatorname{lgG} 1$ & - \\
\hline & CD8a-UNL ${ }^{1}$ & $E P 72 / \lg 2 \mathrm{~b}$ & Goat-anti-mouse-lgG2b-AF790 \\
\hline & $28-4-U N L^{2}$ & $\operatorname{lgG3}$ & Goat-anti-mouse-IgG3-APC/Cy $7^{1}$ \\
\hline & $20 \mathrm{E} 5-\mathrm{BIOT}^{2}$ & $\operatorname{lgG1}$ & SA-PercP $P^{6}$ \\
\hline & IFNY-APC ${ }^{3}$ & MAb80/lgG1 & - \\
\hline \multirow[t]{4}{*}{ T cell proliferation } & CD3-FITC ${ }^{1}$ & CT3/lgG1 & - \\
\hline & CD4-PE/Cy $7^{1}$ & $\mathrm{CT} 4 / \operatorname{lgG} 1$ & - \\
\hline & CD8a-APC 1 & CT8/lgG1 & - \\
\hline & IL-2Ra-UNL ${ }^{2}$ & $28-4 / \operatorname{lgG} 3$ & Goat-anti-mouse-lgG3-PE ${ }^{1}$ \\
\hline
\end{tabular}

Three APC antibody panels were prepared each containing surface markers plus one out of three antibodies indicated $(*)$.

Manufacturer: ${ }^{1}$ Southern Biotech, AL, USA.

${ }^{2}$ Purified antibody from hybridoma supernatant [44], kindly provided by Göbel, T.W., Ludwig Maximilian University, Germany.

${ }^{3}$ Developmental Studies Hybridoma Bank (DSHB), University of lowa, IA, USA.

${ }^{4}$ Serotec, United Kingdom.

${ }^{5}$ Bio-Rad.

${ }^{6}$ BD Biosciences.

${ }^{7}$ Biolegend.

8 Jackson ImmunoResearch Laboratories, PA, USA. 
$0.5 \mu \mathrm{L} / \mathrm{mL}$ mouse-anti-chicken-CD107a-APC for $4 \mathrm{~h}$ at $37{ }^{\circ} \mathrm{C}, 5 \% \mathrm{CO}_{2}$. After incubation, lymphocytes were washed in PBA and stained as described in "Phenotypic characterization of lymphocytes by flow cytometry" section with monoclonal antibodies for NK and $\mathrm{T}$ cells, and anti-CD41/61 to exclude thrombocytes from analyses, as mentioned in the CD107 panel (Table 1). Cells were washed in PBS, stained for viability and analyzed by flow cytometry.

\section{IFNp assay}

Expression of intracellular IFN $\gamma$ was determined in (subsets of) $\mathrm{NK}$ cells, $\gamma \delta \mathrm{T}$ cells, $\mathrm{CD} 4^{+}$and $\mathrm{CD} 8^{+} \mathrm{T}$ cells, using the assay adapted from Ariaans et al. [45]. Lymphocytes isolated from the IEL population and spleen were resuspended in complete medium, and $1 \times 10^{6}$ lymphocytes in $0.5 \mathrm{~mL}$ were incubated in the presence of $1 \mu \mathrm{L} /$ $\mathrm{mL}$ Brefeldin A (Sigma Aldrich) for $4 \mathrm{~h}$ at $41{ }^{\circ} \mathrm{C}, 5 \% \mathrm{CO}_{2}$. After incubation, lymphocytes were washed in PBA and stained as described in "Phenotypic characterization of lymphocytes by flow cytometry" section with surface markers as mentioned in the IFN $\gamma$ panel (Table 1). Cells were washed in PBS, stained for viability and washed again in PBA. Then, lymphocytes were permeabilized differently as described by Ariaans et al. [45]. Lymphocytes were incubated in $200 \mu \mathrm{L}$ of a mixture of BD FACS ${ }^{\mathrm{TM}}$ Permeabilizing Solution 2 and BD FACS ${ }^{\text {TM }}$ Lysing Solution prepared according to manufacturer's instructions (BD Biosciences) for 8 min at RT, immediately followed by centrifugation for $2 \mathrm{~min}$ at $393 \times g$ at $4{ }^{\circ} \mathrm{C}$. Cells were washed twice in PBA, stained intracellularly with antiIFN $\gamma$-APC in $50 \mu \mathrm{L}$ PBA for $20 \mathrm{~min}$ at $4{ }^{\circ} \mathrm{C}$ in the dark, washed in PBA and finally analyzed by flow cytometry.

\section{Phenotypic characterization of APCs by flow cytometry}

Splenocytes isolated at 0, 1, 3 and $7 \mathrm{dpi}$ from infected and uninfected chickens were transferred to a 96 wells V-bottom plate and stained with antibodies of the APC panel to distinguish APC subsets (Table 1). Staining with primary and secondary antibodies $\left(1 \times 10^{6}\right)$ was performed in $50 \mu \mathrm{L} \mathrm{PBA}$, incubated for $20 \mathrm{~min}$ at $4{ }^{\circ} \mathrm{C}$ in the dark and washed twice by centrifugation for $3 \mathrm{~min}$ at $393 \times g$ at $4{ }^{\circ} \mathrm{C}$ in PBA. Finally, the cells were stained in $50 \mu \mathrm{L}$ PBS with ViaKrome 808 viability dye (Beckman Coulter) for $20 \mathrm{~min}$ at $4{ }^{\circ} \mathrm{C}$. Cells were washed in PBA and analyzed by flow cytometry as described in "Phenotypic characterization of lymphocytes by flow cytometry" section, using $180 \mu \mathrm{L}$.

Based on the APC subset staining, a t-distributed Stochastic Neighbor Embedding ( $t-\mathrm{SNE}$ ) analysis was performed using FlowJo software to identify cell subsets using an unbiased approach. From each sample of splenocytes at $7 \mathrm{dpi}$ of infected $(n=5)$ and uninfected $(n=5)$ chickens, 10000 cells were taken and concatenated into one FCS file that represented all individual chickens. The $\mathrm{t}$-SNE was performed based on expression levels of CD3, CD41/61, MRC1LB, CD4, Bu-1, CD11, MHC-II and $\mathrm{CHIR-AB1}$ using published automated optimized parameters [46]. Based on the t-SNE, three APC subsets were identified based on selection of MRC1LB and CD11 positive cells, which were negative for CD3, CD4 and CD41/61. Activation status of the subsets was subsequently evaluated using the expression percentages of immunoglobulin Y receptor CHIR-AB1, co-stimulatory molecules $\mathrm{CD} 40$ and $\mathrm{CD} 80$, and the geometric mean fluorescent intensity (gMFI) of MHC-II. CHIR-AB1 was included as an activation marker since surface expression of this marker has been described to be induced on macrophages upon stimulation with LPS or IFN- $\gamma$, which was recently confirmed by van den Biggelaar et al. $[47,48]$.

\section{Fluorescence-activated cell sorting of NK cell and APC subsets}

Based on marker expression, two NK cell subsets and three APC subsets were separated by fluorescenceactivated cell sorting (FACS) to gain more insight into their functional identity. To distinguish NK cell subsets, splenocytes were stained with mouse-anti-chickenCD3-APC, -Bu-1-FITC, -28-4 and -20E5-biotin. For secondary antibody staining goat-anti-mouse-IgG3-PE and SA-BV421 were used. To identify APC subsets, splenocytes were stained with mouse-anti-chicken-MRC1LBPE and -CD11-biotin. Secondary staining with SA-BV605 was used to fluorescently label CD11-biotin. To assess viability, the cells were stained with the Zombie Aqua ${ }^{\mathrm{TM}}$ Fixable Viability Kit. Primary and secondary antibody staining of cells used the same conditions as described in "Phenotypic characterization of lymphocytes by flow cytometry" section. Finally, the cells were resuspended in PBA (NK cells) or PBA with $2 \mathrm{mM}$ EDTA- $\mathrm{Na}_{2}$ (APC subsets), and isolated by FACS using the BD influx ${ }^{\text {TM }}$ Cell Sorter and 405-, 488-, 638-, 561- and 640-nm lasers. The cells were gated for viability and subsequently sorted into $\mathrm{CD}^{-} \mathrm{Bu}-1^{-} 28-4^{+}\left(\mathrm{IL}-2 \mathrm{R}^{+} \mathrm{NK}\right), \mathrm{CD}^{-} \mathrm{Bu}-1^{-} 20 \mathrm{E} 5^{+}$

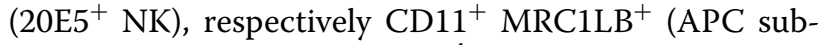
set 1 ), $\mathrm{CD}^{+} 1^{+} \mathrm{MRC}^{-} \mathrm{LB}^{-} \mathrm{FSC}^{\text {low }}$ (APC subset 2a) and $\mathrm{CD}_{11}{ }^{+} \mathrm{MRC}^{-} \mathrm{LB}^{-} \mathrm{FSC}^{\text {high }}$ (APC subset 2b). The sorted NK cell subsets were collected in $350 \mu \mathrm{L}$ RLT buffer (Qiagen, the Netherlands) with 1\% 2-mercaptoethanol (Sigma Aldrich). The sorted APC subsets, and the original (unsorted) cell population as a control, were centrifuged at $393 \times g$ for $5 \mathrm{~min}$ and then lysed in $600 \mu \mathrm{L}$ RLT buffer with 1\% 2-mercaptoethanol. Cell lysates of sorted cell subsets and the control cell population were then stored at $-20^{\circ} \mathrm{C}$ until RNA isolation and qPCR analysis. 
Gene expression of separated subsets of NK cells and APCs Target genes (Table 2) were selected based on literature to define functional differences between subsets of NK cells respectively APCs. RNA was isolated from lysates of sorted NK and APC subsets, and control cells, using the RNeasy Mini Kit (Qiagen) according to the manufacturer's instructions, including a DNase treatment using the RNase-Free DNase Set (Qiagen). Next, cDNA was prepared using the reverse transcriptase from the iScript cDNA Synthesis Kit (Bio-Rad) according to the manufacturer's instructions. RT-qPCRs were performed with primers and either FAM-TAMRA-labeled TaqMan probes combined with TaqMan Universal PCR Master Mix or SYBR Green Master Mix without probes (all from Thermo Fisher Scientific), as indicated in Table 2. Primers were used at $400 \mathrm{nM}$ (SYBR-Green) or $600 \mathrm{nM}$ (Taqman) and probes at $100 \mathrm{nM}$. RT-qPCRs were performed with a
CFX Connect and analyzed with CFX Maestro software (both from Bio-Rad). All RT-qPCRs were evaluated for proper amplification efficiency (95-105\%) using serial dilutions of reference cDNA either from splenocytes that were stimulated with Concanavalin A for $24 \mathrm{~h}$ or from HD11 cells that were stimulated with LPS for $3 \mathrm{~h}$. RT-qPCRs were performed in triplicate for every sample. For the NK cell subsets, mRNA levels are expressed as $40-\mathrm{Ct}$ and the cycle threshold value $(\mathrm{Ct})$ was corrected for variations in RNA preparation and sampling using the GAPDH Ct values, as described elsewhere [49]. Higher gene expression of NFIL3 3 and $I L-7 \alpha$ is indicative of the cytokine-producing NK cell subset in humans [50-54], whereas higher expression of PRF1 is indicative of the cytotoxic NK cell subset in humans and chickens $[52,55]$. Gene expression levels of the APC subsets are shown relative to those of unsorted splenocytes. Furthermore, $\mathrm{Ct}$

Table 2 Primers and TaqMan probe sequences used for RT-qPCR

\begin{tabular}{|c|c|c|c|c|c|}
\hline Cell type & Genes & NCBI Reference & TaqMan/SYBR-Green & Type & Sequence $\left(5^{\prime}-3\right)$ \\
\hline \multirow[t]{8}{*}{ NK cells } & NFIL3 & XM_017014743.1 & SYBR-Green & Forward & TGAATGCCATCAGTTGAGC \\
\hline & & & & Reverse & GAGAGGCGGAGAATGTGAGT \\
\hline & IL-7Ra & NM_001080106.1 & SYBR-Green & Forward & ATTCTGGGAAAGCAGGATCAAG \\
\hline & & & & Reverse & CTTACACAGTCGCTCCAGAGTTATTT \\
\hline & PRF1 & XM_004945690.3 & SYBR-Green & Forward & ACCCGCACCAAAAGATGAAG \\
\hline & & & & Reverse & TAATTCGCACACCCCTAAACG \\
\hline & GAPDH & NM_204305.1 & SYBR-Green & Forward & GTGGTGCTAAGCGTGTTATC \\
\hline & & & & Reverse & GCATGGACAGTGGTCATAAG \\
\hline \multirow[t]{22}{*}{ APCs } & CD14 & NM_001139478.1 & TaqMan & Forward & GGACGACTCCACCATTGACAT \\
\hline & & & & Reverse & GGAGGACCTCAGGAACCAGAA \\
\hline & & & & Probe & AATGATCTTCCTGATTTGCAGACTGCCAA \\
\hline & $T L R 4$ & NM_001030693.1 & SYBR-Green & Forward & GTCCCTGCTGGCAGGAT \\
\hline & & & & Reverse & TGTCCTGTGCATCTGAAAGCT \\
\hline & MERTK & NM_204988.1 & SYBR-Green & Forward & TGTGGAAGGATGGCAGGGAG \\
\hline & & & & Reverse & GCACGGATGCTGAATGTAGAGG \\
\hline & $M A F B$ & NM_001030852.1 & SYBR-Green & Forward & AGGACCGGTTCTCGGATGAC \\
\hline & & & & Reverse & CCTCGGAGGTGCCTGTTG \\
\hline & INOS & NM_204961.1 & SYBR-Green & Forward & TGGGTGGAAGCCGAAATA \\
\hline & & & & Reverse & GTACCAGCCGTTGAAAGGAC \\
\hline & ZBTB46 & XM_015296613.2 & SYBR-Green & Forward & CTGGACCTGTGGAAGAGGAAAC \\
\hline & & & & Reverse & CGGTAGTGGGAGGCAATCTC \\
\hline & $X C R 1$ & NM_001024644.2 & SYBR-Green & Forward & CCTTCGGGTGGATTTTTGGT \\
\hline & & & & Reverse & CGCTGTAGTAGCCAATGGAGAA \\
\hline & FLT3 & NM_004119.3 & SYBR-Green & Forward & CATTCGGACCCAGTACATGTTTAC \\
\hline & & & & Reverse & TGAGCCGTAGAAGAGCAGGTATAA \\
\hline & GAPDH & NM_204305.1 & SYBR-Green & Forward & GTGGTGCTAAGCGTGTTATC \\
\hline & & & & Reverse & GCATGGACAGTGGTCATAAG \\
\hline & 285 & XR_00378040.1 & TaqMan & Forward & GGCGAAGCCAGAGGAAACT \\
\hline & & & & Reverse & GACGACCGATTTGCACGTC \\
\hline & & & & Probe & AGGACCGCTACGGACCTCCACCA \\
\hline
\end{tabular}


gene expression values were normalized to housekeeping genes $28 S$ and GAPDH. Changes in gene expression after sorting was expressed as $2^{-\Delta \Delta \mathrm{Ct}}$, according to the Livak method [56]. Enrichment of cells expressing CD14, TLR4, MERTK and MAFB after sorting of cells was considered indicative for a monocyte/macrophage phenotype, whereas enrichment of cells expressing ZBTB46, $X C R 1$ and FLT3 after sorting was considered indicative

\section{SE-specific antibody titers in serum}

To detect titers of SE-specific antibodies in the sera collected at $0,7,14$ and $21 \mathrm{dpi}$, the commercially available Salmonella Enteritidis Antibody Test (IDEXX SE Ab X2 Test) was used according to manufacturer's instructions (IDEXX Europe, the Netherlands). Positive and negative controls were included in the kit, and serum samples were analyzed in duplicate. Endpoint titers were calculated with the following formula:

$10^{(1.5 \times \log 10((\text { sample } \mu-\text { negative control } \mu) /(\text { positive } \mu \text {-negative control } \mu))+3.47)}$.

for a DC phenotype, in accordance with previous studies $[57,58]$.

\section{T cell proliferation assay}

Splenocytes isolated at $21 \mathrm{dpi}$ from uninfected and SEinfected chickens were labelled with CellTrace Violet (CTV, Invitrogen) to measure proliferation by flow cytometry. The cells were resuspended at $5 \times 10^{6}$ cells/ $\mathrm{mL}$ in PBS with $5 \mu \mathrm{M} \mathrm{CTV}$ and incubated for $20 \mathrm{~min}$ at $\mathrm{RT}$, while the cell suspension was vortexed every $5 \mathrm{~min}$. Next, the labeling was quenched by the addition of $5 \mathrm{~mL}$ complete medium for every $\mathrm{mL}$ of CTV staining solution and incubated for $5 \mathrm{~min}$ at RT. Cells were centrifuged for $5 \mathrm{~min}$ at $335 \times g$ at $20{ }^{\circ} \mathrm{C}$ and resuspended at $2.5 \times 10^{6}$ cells $/ \mathrm{mL}$ in X-VIVO 15 cell culture medium (Lonza) with $50 \mathrm{U} / \mathrm{mL}$ penicillin-streptomycin, $50 \mu \mathrm{M}$ 2-mercaptoethanol (Sigma Aldrich) and $50 \mu \mathrm{g} / \mathrm{mL}$ gentamycin $\left(\mathrm{Gibco}^{\mathrm{TM}}\right)$. Aliquots of $200 \mu \mathrm{L}$ cell suspension containing 500000 splenocytes were added to the wells of a 96 wells round-bottom cell culture plate. Fixed SE was added to the splenocytes at $10^{4}, 10^{5}$ or $10^{6} \mathrm{CFU} /$ well. As a positive control, splenocytes were stimulated with $1 \mu \mathrm{g} / \mathrm{mL}$ mouse-anti-chicken-CD3, $1 \mu \mathrm{g} / \mathrm{mL}-\mathrm{CD} 28$ and 1:50 diluted conditioned supernatant from COS-7 cells transfected with a pcDNA1 vector (Invitrogen) encoding for recombinant chicken IL-2 (a kind gift from prof. Pete Kaiser and Lisa Rothwell), in accordance with a previous publication [59]. Cells were incubated for 4 days at $41^{\circ} \mathrm{C}$ and $5 \% \mathrm{CO}_{2}$. After incubation, cells were transferred to a 96 wells V-bottom plate and stained in PBS with ViaKrome 808 viability dye (Beckman Coulter). Next, cells were stained with antibodies of the $\mathrm{T}$ cell proliferation panel (Table 1). Primary and secondary staining of cells were conducted in $30 \mu \mathrm{L}$ PBA and incubated for $20 \mathrm{~min}$ at $4{ }^{\circ} \mathrm{C}$ in the dark. Stained cells were washed twice by centrifugation for $3 \mathrm{~min}$ at $393 \times g$ at $4{ }^{\circ} \mathrm{C}$ in PBA and resuspended in $100 \mu \mathrm{L}$ followed by flow cytometry analysis as described in "Phenotypic characterization of lymphocytes by flow cytometry" section, using $80 \mu \mathrm{L}$.

\section{Statistical analysis}

First, the data were tested for fitting a normal distribution using the Shapiro-Wilk test. Differences in numbers of IELs or leukocytes, NK cell and T cell subsets and percentages of CD107 and IFNY expression in the IELs and spleen between the uninfected and SE-infected groups as well as within each group in the course of time were analyzed using one-way ANOVA tests. Differences in SE CFUs per gram ileum and spleen as well as SE-specific antibody titers in serum were analyzed using KruskalWallis tests accompanied by Dunn's multiple comparisons tests. Differences in numbers and percentages of the splenic APC subsets 1 and $2 \mathrm{a}$ between the uninfected and SE-infected groups were analyzed using one-way ANOVA tests, while subset $2 b$ was analyzed using the Kruskal-Wallis test as the data was not normally distributed. All statistical analyses were performed using GraphPad Prism 9 software (GraphPad Software, CA, USA). A $p$-value of $<0.05$ was considered statistically significant and a value of $0.05<p<0.1$ is referred to as a trend, in case the $p$-value did not belong to one of these categories it is referred to as a numerical difference.

\section{Results}

Highest presence of SE in ileum and spleen at $7 \mathrm{dpi}$ while intestinal infiltration of IELs was observed at $1 \mathrm{dpi}$ SE was not observed at -4 and 0 dpi before SE inoculation, in both the IEL population of the ileum and the spleen of chickens of both groups (Figures $1 \mathrm{~A}$ and B). After inoculation SE was detected in the ileum of SEinfected chickens only at $7 \mathrm{dpi}$ (Figure 1A). In the spleen, SE was observed at 7, 14 and $21 \mathrm{dpi}$ with the highest bacterial counts at $7 \mathrm{dpi}$, which subsequently decreased in course of time (Figure 1B). SE was not detected in the ileum and spleen of uninfected chickens at any of the time points (Figures $1 \mathrm{~A}$ and B). One uninfected chicken showed counts of Proteus in the spleen at $7 \mathrm{dpi}$ and was therefore excluded from further analyses. Infection with SE did not affect the weight of the chickens, as growth 

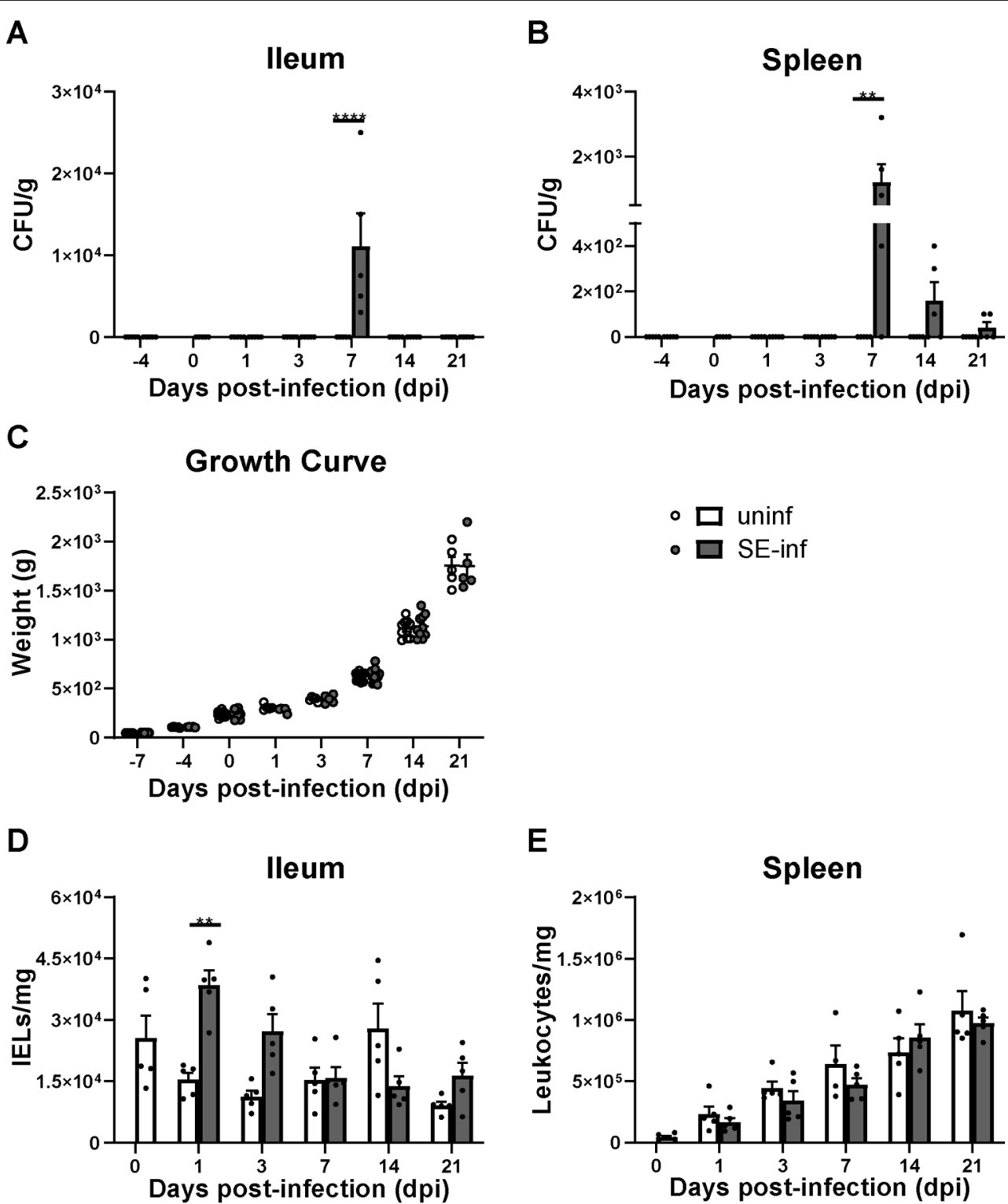

Figure 1 The bacterial load in course of time after SE infection and its effect on growth and numbers of IELs and splenic leukocytes. A Salmonella enterica serotype Enteritidis (CFU/g) in the ileum and B spleen of uninfected (uninf) and SE-infected chickens (SE-inf). The LOD was 100 CFU per gram tissue. C Bodyweights (g) of uninfected and SE-infected chickens in the course of time. D Numbers (cells/mg) of IELs per mg ileum and $\mathbf{E}$ leukocytes per $\mathrm{mg}$ spleen of uninfected and SE-infected chickens in the course of time. Mean + SEM per treatment and time point is shown $(n=5)$ and statistical significance is indicated as ${ }^{* *} p<0.01$ and ${ }^{* * *} p<0.0001$.

curves were similar between uninfected and SE-infected chickens (Figure 1C). A significant increase in numbers of IELs was found in SE-infected chickens at $1 \mathrm{dpi}$ compared to uninfected chickens (Figure 1D). IELs were numerically higher at $3 \mathrm{dpi}$ in SE-infected chickens and declined over time to numbers similar to those observed in uninfected chickens (Figure 1D). The numbers of splenic leukocytes were similar between uninfected and SE-infected chickens at all time points (Figure 1E).

\section{Enhanced activation of intraepithelial NK cells upon SE} infection

Numbers of intraepithelial and splenic NK cell subsets were determined to investigate differences between uninfected and SE-infected chickens at several time points post-infection. NK cell subsets were distinguished by membrane expression of IL-2R $\alpha$ or $20 \mathrm{E} 5$ (Additional file 1). Although no significant differences were observed in numbers of intraepithelial NK cell subsets, 

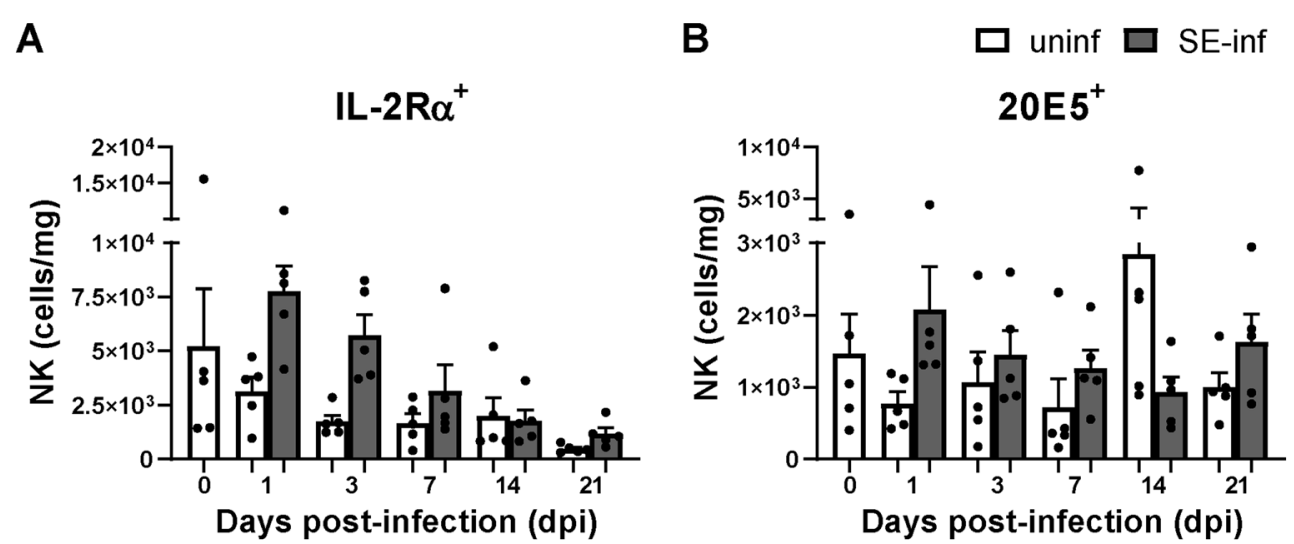

Figure 2 Effect of SE infection on numbers of intraepithelial NK cells in broiler chickens. A Numbers (cells/mg) of intraepithelial IL-2Ra ${ }^{+}$and B 20E5 ${ }^{+}$NK cells per mg ileum, in uninfected (uninf) and SE-infected (SE-inf) chickens. Mean + SEM per treatment and time point is shown ( $n=5$ ).

IL-2R $\alpha^{+}$and $20 \mathrm{E} 5^{+} \mathrm{NK}$ cells were numerically higher in SE-infected chickens at 1, 3 and $7 \mathrm{dpi}$ compared to uninfected chickens (Figures 2A and B). Furthermore, intraepithelial $20 \mathrm{E} 5^{+} \mathrm{NK}$ cells were numerically lower at $14 \mathrm{dpi}$ and higher at $21 \mathrm{dpi}$ in SE-infected compared to uninfected chickens (Figure 2B). In the control group, no significant differences were observed in the numbers of intraepithelial NK cells in course of time. In the spleen, numbers of $\mathrm{IL}-2 \mathrm{R} \alpha^{+}$and $20 \mathrm{E} 5^{+}$NK cells were similar between uninfected and SE-infected chickens and both increased in course of time (Additional files 2A and B). To obtain more insight in functional differences between IL-2R $\alpha^{+}$and $20 \mathrm{E} 5^{+}$NK cells, mRNA levels of genes deemed to be relevant were determined in the spleen. The IL-2R $\alpha^{+}$subset showed numerical higher mRNA levels of the NK cell lineage marker NFIL3 and IL-7R $\alpha^{+}$ as compared to the $20 \mathrm{E} 5^{+}$subset, whereas the $20 \mathrm{E} 5^{+}$ subset showed a numerical higher mRNA level of perforin as compared to the IL- $2 \mathrm{R}^{+}$subset (PRF1, Additional file $2 \mathrm{C}$ ).

To determine possible changes in NK cell activation upon SE infection, CD107 surface expression and intracellular IFN $\gamma$ were analyzed in intraepithelial and splenic NK cells (Figure 3A). Intraepithelial NK cells showed a significant increase in surface expression of CD107 and IFN $\gamma$ production in SE-infected chickens at $1 \mathrm{dpi}$ and 3 dpi compared to uninfected chickens (Figures $3 \mathrm{~B}$ and $\mathrm{C}$ ). In the spleen, a significant increase in surface expression of CD107 was observed at $1 \mathrm{dpi}$ and $3 \mathrm{dpi}$, and a significant increase in IFN $\gamma$ production was observed at $1 \mathrm{dpi}$, 3 dpi and 7 dpi in SE-infected compared to uninfected chickens (Figures 3D and E).

\section{Increased presence of APCs in the spleens of SE-infected chickens}

To investigate whether infection with SE affects the composition of the APC population, amongst splenocytes, these were stained for APC surface markers and analyzed by flow cytometry. A t-SNE analysis was used to determine the differences in APCs between uninfected and SE-infected chickens (Figures $4 \mathrm{~A}-\mathrm{C}$ and Additional file $3 \mathrm{~A})$. This analysis clustered cells that have high similarity and separated cells that are unrelated based on the APC surface markers that were used, leading to an unbiased visualization of all cell populations. Two populations were found overrepresented in the spleen of SE-infected chickens (Figure 4B). By gating for subset 1 and 2 and assessing their expression of APC markers, subset 1 was identified as $\mathrm{CD}_{11}{ }^{+} \mathrm{MRC}_{\mathrm{LBB}}{ }^{+}$and subset 2 as $\mathrm{CD} 11^{+}$ MRC1LB ${ }^{-}$(Figure 4C, first panel). In addition, subset 2 could be further divided into two subsets, distinguished by FSC-A and SSC-A characteristics, that were further analyzed separately (Figure $4 C$, second panel).

The APC subsets were sorted (Additional files $3 B$ and $\mathrm{C}$ ), and qPCR was performed to compare the expression levels of macrophage- and DC-specific genes between sorted cells and the unsorted total APC population. High expression levels of the monocyte/macrophage genes CD14, TLR4, MERTK and MAFB (Figure 4D) observed on the $\mathrm{CD} 11^{+} \mathrm{MRC} \mathrm{LB}^{+}$cells, indicates that this subset 1 includes macrophages (hereafter referred to as macrophages). The $\mathrm{CD}_{11}{ }^{+} \mathrm{MRC}_{\mathrm{LLB}}{ }^{-} \mathrm{FSC}^{\text {high }}$ subset $2 \mathrm{~b}$ includes DCs as reflected by high expression of the DC genes ZBTB46, XCR1 and FLT3 (hereafter referred to as $\mathrm{FSC}^{\text {high }} \mathrm{DCs}$ ) (Figure 4D). The increase in expression of either macrophage- or DC-specific genes was less clear in the $\mathrm{CD}_{11}{ }^{+} \mathrm{MRC}_{1} \mathrm{LB}^{-} \mathrm{FSC}^{\text {low }}$ subset 2a, however, 


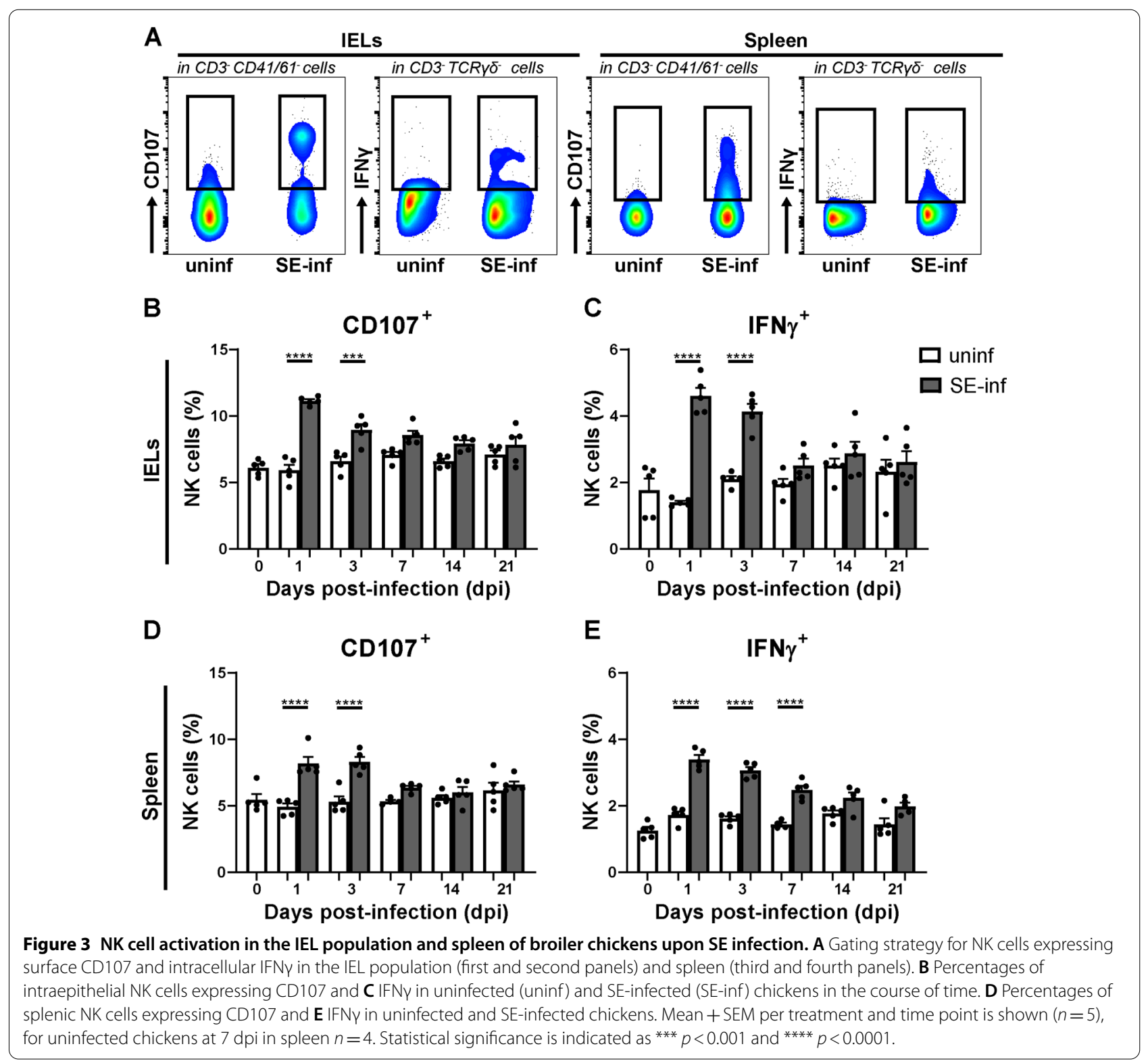

DC-specific genes were most abundantly expressed (hereafter referred to as FSC ${ }^{\text {low }}$ DCs) (Figure 4D).

Next, the percentages (Figure $4 \mathrm{E}$ and Additional file $4 \mathrm{~A}$ and $\mathrm{B}$ ) and numbers (Figure $4 \mathrm{~F}$ and Additional file $4 \mathrm{C}$ and D) of the three APC subsets were followed over time in the spleens of uninfected and SE-infected chickens. Due to limited cell numbers, the analysis of APCs could not be performed for two chickens at $0 \mathrm{dpi}$. At $7 \mathrm{dpi}$, the percentage of macrophages was significantly increased in SE-infected compared to uninfected chickens (Figure 4E). The $\mathrm{FSC}^{\text {low }}$ (Additional file 4A and $C$ ) and FSC $^{\text {high }}$ (Additional file $4 \mathrm{~B}$ and D) DCs were similar in SE-infected compared to uninfected chickens at all time points, although a slight increase in both the percentages and numbers of FSC ${ }^{\text {high }}$ DCs was observed at $7 \mathrm{dpi}$ (Additional file $4 \mathrm{~B}$ and $\mathrm{D}$ ).

\section{APCs become activated in spleens of SE-infected chickens}

To assess the activation status of the three APC subsets in response to SE infection, expression levels of immunoglobulin $\mathrm{Y}$ receptor CHIR-AB1, co-stimulatory molecules CD40 and CD80, and MHC-II were evaluated by flow cytometry (Additional file 5 ). The macrophages of SE-infected chickens showed significantly decreased expression of the activation markers CD40 ( 1 and $7 \mathrm{dpi}$ ) and CD80 (7 dpi), whereas expression of CHIR-AB1 and MHC-II was similar compared to uninfected chickens (Figure 5A, D, G, J). Before infection, FSC ${ }^{\text {low }}$ DCs 
of uninfected chickens showed a higher expression of MHC-II (Figure 5K, L) and more cells that were positive for the costimulatory molecules CD40 (Figure 5E, F) and CD80 (Figure 5H, I) compared to FSC high DCs. At $7 \mathrm{dpi}$, FSC $^{\text {low }}$ DCs showed significantly increased expression of CHIR-AB1 (Figure 5B), CD40 (Figure 5E) and CD80 (Figure 5H) in SE-infected chickens as compared to uninfected chickens. The FSC ${ }^{\text {high }}$ DCs showed at 7 dpi significantly increased expression of CHIR-AB1 (Figure 5C) and MHC-II (Figure 5L) in SE-infected compared to uninfected chickens. In course of time, expression of CD40 by macrophages significantly increased at $1 \mathrm{dpi}, 3 \mathrm{dpi}$ and $7 \mathrm{dpi}$ as compared to $0 \mathrm{dpi}$ in the control group (Figure 5D). In addition, CD80 expression by macrophages significantly increased at $3 \mathrm{dpi}$ as compared to 0 dpi in the control group (Figure 5G).

\section{Increased presence of intraepithelial cytotoxic T cells at 1 $\mathrm{dpi}$ and proliferation of SE-induced splenic T cells ex vivo at $21 \mathrm{dpi}$}

Numbers of $\gamma \delta$ T cells and cytotoxic $\left(C D 8^{+}\right) \alpha \beta$ T cells were determined in course of time in the IEL population and spleen of uninfected and SE-infected chickens (Additional file 1). Although numbers of intraepithelial $\gamma \delta \mathrm{T}$ cells did not significantly differ, they were numerically higher at 1 and $3 \mathrm{dpi}$, as well as at $21 \mathrm{dpi}$ in SE-infected compared to uninfected chickens (Figure 6A). A significant increase in numbers of intraepithelial cytotoxic $\mathrm{CD}^{+} \mathrm{T}$ cells was observed at $1 \mathrm{dpi}$, and at $3 \mathrm{dpi}$ and 21 dpi intraepithelial cytotoxic $\mathrm{CD}^{+} \mathrm{T}$ cells were numerically higher in SE-infected compared to uninfected chickens (Figure 6B). In the spleen, $\gamma \delta \mathrm{T}$ cells were numerically decreased at $1 \mathrm{dpi}$ but increased at $3 \mathrm{dpi}$ in SE-infected compared to uninfected chickens (Figure 6C). Numbers of splenic cytotoxic $\mathrm{CD}^{+} \mathrm{T}$ cells were similar between uninfected and SE-infected chickens during the course of infection (Figure 6D). Next, $\gamma \delta$ T cells and cytotoxic $\alpha \beta \mathrm{T}$ cells were analyzed for their CD8 $\alpha \alpha$ and CD8 $\alpha \beta$ expression (Additional file 1). Numbers of intraepithelial $\mathrm{CD} 8 \alpha \alpha^{+} \gamma \delta \mathrm{T}$ cells (Additional file $6 \mathrm{~A}$ ) were significantly increased at $1 \mathrm{dpi}$ and $21 \mathrm{dpi}$, and $C D 8 \alpha \beta^{+} \gamma \delta \mathrm{T}$ cells (Additional file 6B) were numerically higher at those time points in SE-infected compared to uninfected chickens. Similarly, numbers of intraepithelial cytotoxic CD8 $\alpha \alpha^{+} \mathrm{T}$ cells (Additional file 6C) were significantly increased at 1 $\mathrm{dpi}$ and they were numerically higher at $21 \mathrm{dpi}$. The cytotoxic $C D 8 \alpha \beta^{+} \mathrm{T}$ cells (Additional file $6 \mathrm{D}$ ) were numerically higher at those time points in SE-infected compared to uninfected chickens. In the spleen, CD8 $\alpha \alpha^{+} \gamma \delta \mathrm{T}$ cell numbers (Additional file $6 \mathrm{E}$ ) were significantly increased at $14 \mathrm{dpi}$, whereas numbers of $\mathrm{CD} 8 \alpha \beta^{+} \gamma \delta \mathrm{T}$ cells (Additional file $6 \mathrm{~F}$ ) were similar in SE-infected versus uninfected chickens. Numbers of splenic cytotoxic CD $8 \alpha \alpha^{+}$ (Additional file 6G) and CD8 $\alpha \beta^{+}$(Additional file $6 \mathrm{H}$ ) $\mathrm{T}$ cells as well helper $\mathrm{CD} 4^{+} \mathrm{T}$ cells (Additional file 7) were similar between uninfected and SE-infected chickens during the course of infection. Finally, no significant differences were observed in T cell activation, determined by $\mathrm{CD} 107$ and IFNY expression, in the IEL population and spleen between uninfected and SE-infected chickens (Additional file 8). Although expression of CD107 was numerically higher at $3 \mathrm{dpi}$ by intraepithelial and splenic $\mathrm{CD}^{+} \mathrm{T}$ cells (comprising both $\gamma \delta$ and $\alpha \beta$ TCRs, Additional file $8 \mathrm{~A}$ and $\mathrm{B}$ respectively), as well as expression of IFN $\gamma$ by splenic $\mathrm{CD}^{+}{ }^{+} \mathrm{T}$ cells (Additional file $8 \mathrm{D}$ ) in SEinfected compared to uninfected chickens. Expression of IFN $\gamma$ by $\mathrm{T}$ cell subsets in the IEL population could not be determined due to too low cell numbers.

$\mathrm{SE}$-induced proliferation of $\mathrm{T}$ cells, isolated from spleen at $21 \mathrm{dpi}$, was determined ex vivo (Figure $7 \mathrm{~A}$ ). Increased proliferation of SE-induced $\mathrm{CD} 4^{+}$as well as $\mathrm{CD} 8^{+} \mathrm{T}$ cells isolated from SE-infected chickens was observed. This proliferation was antigen dose-dependent, whereas $\mathrm{T}$ cells from uninfected chickens did not proliferate upon exposure to inactivated SE (Figure 7B, C).

\section{High SE-specific antibody responses were found in all SE-infected chickens after 3 weeks of infection}

The presence of SE-specific antibodies was determined in serum before and after infection in uninfected and SE-infected chickens. In SE-infected chickens, SE-specific antibodies were first detected at $7 \mathrm{dpi}$, when two out of five chickens showed low antibody titers, that

\footnotetext{
(See figure on next page.)

Figure 4 Phenotypic characterization of splenic APCs upon SE infection. A Splenocytes were gated for size, excluding debris (FSC-A vs SSC-A), singlets (FSC-A vs FSC-H) and viability (Live/Dead marker-negative) consecutively. B A t-SNE analysis was performed on spleen samples of 7 dpi uninfected (uninf, blue) and SE-infected (SE-inf, red) chickens combined. Based on the t-SNE analysis, two population (subset 1 and subset 2) were found enriched among the splenocytes of SE-infected chickens. C The populations were evaluated for expression of MRC1LB versus CD11. Subset 2 was evaluated for its FSC-A vs SSC-A scatter pattern and further subdivided into subset $2 a$ and subset 2b. D Subset $1\left(\mathrm{CD} 11^{+} \mathrm{MRC} 1 \mathrm{LB}^{+}\right)$, subset $2 \mathrm{a}$ $\left(\mathrm{CD} 11^{+} \mathrm{MRC1LB}^{-} \mathrm{FSC}^{\mathrm{low}}\right)$ and subset $2 \mathrm{~b}\left(\mathrm{CD} 11^{+} \mathrm{MRC}_{1 \mathrm{LB}^{-}} \mathrm{FSC}^{\text {high }}\right)$ were sorted by FACS to assess gene expression of immune markers by RT-qPCR relative to the total splenocyte population. $\mathbf{E}$ The presence (\%) and $\mathbf{F}$ numbers (cells/mg spleen) of macrophages in uninfected and SE-infected chickens were assessed over time. Mean + SEM per treatment and time point is shown $(n=5)$, for uninfected chickens at $0 \mathrm{dpi} n=3$ and at $7 \mathrm{dpi}$ $n=4$. Statistical significance is indicated as ${ }^{* *} p<0.01$.
} 


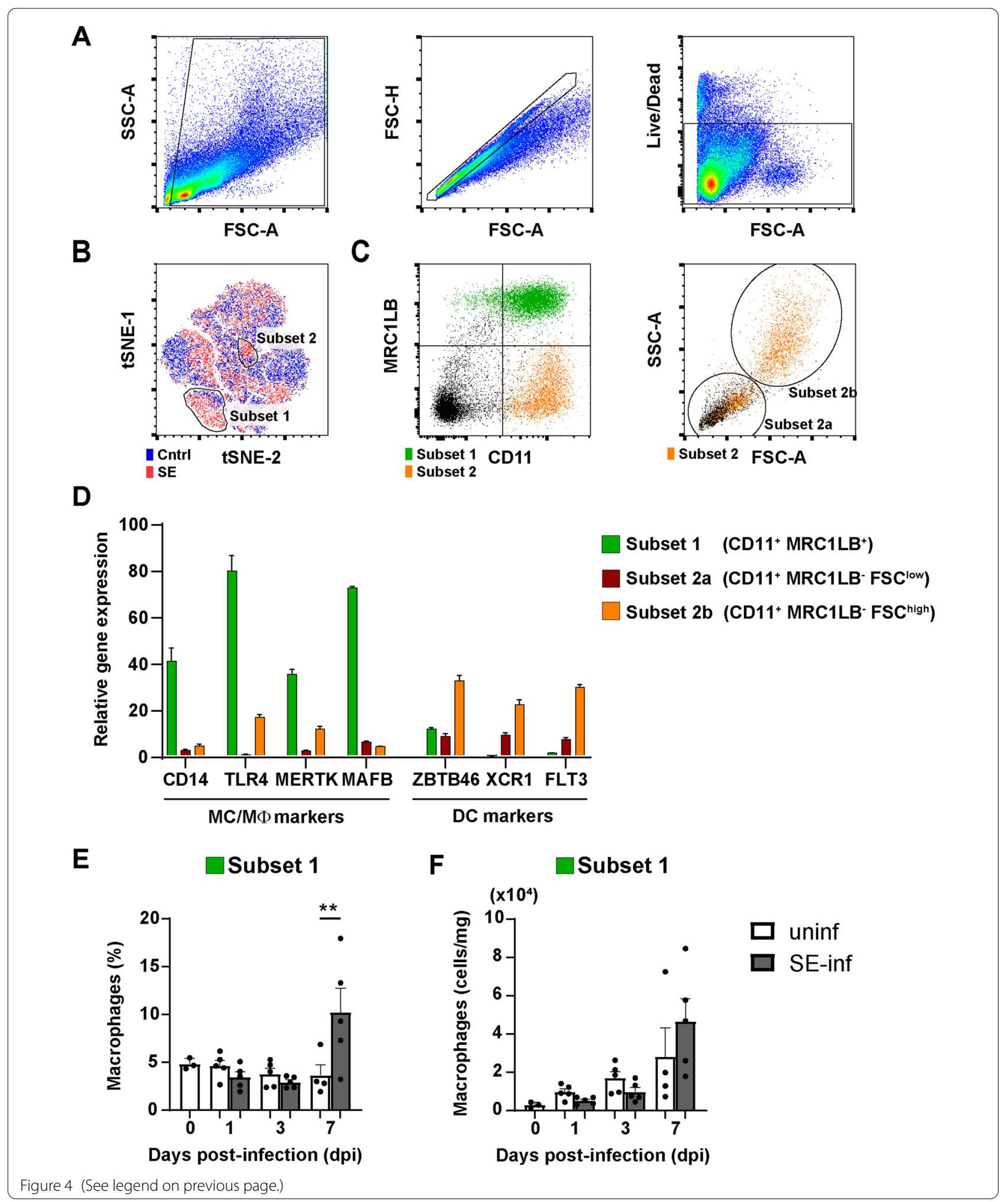

increased in course of time (Figure 8). At 14 dpi SE-specific antibodies were observed in all SE-infected chickens although two chickens showed only low titers. At $21 \mathrm{dpi}$ all SE-infected chickens showed high SE-specific antibody responses. SE-specific antibodies were not found in sera of the uninfected chickens (Figure 8). 


\section{Discussion}

In the current study we aimed to provide a detailed analysis of SE-related innate and adaptive immune responses in young broiler chickens up to 4 weeks of age, to better understand how the immune response contributes to the elimination of infection in course of time. For this purpose, the presence and function of NK cells, various types of APCs and T cells in ileum, as the present infection site and in spleen, as indication of systemic dissemination of SE, were investigated, as well as SE-specific antibody responses in serum, another systemic dissemination indicator. Seven-dayold broiler chickens were successfully infected with SE as was demonstrated by the detection of SE-induced $\mathrm{T}$ cell proliferation and SE-specific antibodies from 2-3 weeks after infection. Presence of SE was detected in ileum only at day 7 post-infection and in spleen from day 7 onwards and most likely, the number of bacteria in these tissues were below the detection limit during the first week post-infection as observed previously [43]. In the first week post-infection, significant increases in numbers of intraepithelial cytotoxic $\mathrm{T}$ cells and splenic macrophages were observed in SE-infected compared to uninfected chickens. This was paralleled by a significant increase in NK cell activation in the IEL population and spleen as well as DC activation in the spleen in SE-infected compared to uninfected chickens. At $21 \mathrm{dpi}$, antibody titers in serum were significantly increased in SE-infected compared to uninfected chickens. These immune responses were paralleled by a reduction in SE counts.

Although presence of SE was demonstrated in ileum and spleen of infected chickens, SE infection did not affect growth nor induced severe disease symptoms. This observation was similar to previous studies in young broiler chickens that were infected at 7 or 9 to 11 days of age $[40,60]$ and in layer chickens that were infected during adult life $[20,43]$. The absence of severe disease symptoms is related to the SE-dose, which was chosen to avoid welfare issues in the chickens. Although SE has been detected in the small intestine [61,62], other studies reported the presence of SE for a longer period in the caecum $[40,41]$. This suggests that SE may prefer colonization in the caecum rather than the ileum.
The enhanced activation of intraepithelial and splenic NK cells upon SE infection, represented by enhanced $\mathrm{CD} 107$ expression and IFN $\gamma$ production, is in agreement with other studies in chickens showing upregulated mRNA levels of intestinal IFN $\gamma$ [20] and cytotoxicityrelated NK cell genes [19] in young chickens. Our observations are also supported by studies in humans and mice, which reported increased cytotoxicity [23], IFNy production [25] and CD107 expression [24] of intestinal and systemic NK cells after Salmonella enterica serotype Typhimurium infection. The enhanced NK cell activation paralleled numerically increased intraepithelial IL- $2 \mathrm{R}^{+}$ and $20 \mathrm{E} 5^{+}$NK cells. Although we did not observe a distinct population of IL-2R $\alpha^{+} 20 \mathrm{E} 5^{+}$cells, we cannot exclude the possibility that these cells exist at a very low frequency. Due to incompatibility of available reagents, we were not able to determine CD107 and IFN $\gamma$ expression within the IL-2R $\alpha^{+}$and $20 \mathrm{E} 5^{+} \mathrm{NK}$ cell subsets. For that reason, we sorted IL-2R $\alpha^{+}$and $20 \mathrm{E} 5^{+} \mathrm{NK}$ cells to perform RT-qPCR and both NK cell subsets showed mRNA levels of NFIL3, IL-7R $\alpha$ and PRF1 genes albeit to different degrees, suggesting that both may be implicated in cytokine production [50-52] as well as cytotoxic activity $[52,55]$ in response to SE infection. The observation that both NK cell subsets are involved in cytotoxicity is confirmed by previous studies in chickens, in which both NK cell subsets in the IEL population and spleen showed CD107 expression [12] and intraepithelial IL-2R $\alpha^{+} \mathrm{NK}$ cells exerted cytotoxicity [11]. In humans, the peripheral IL-2R $\alpha^{+}$NK cell population expanded and increased their cytotoxic activity after Toll-like receptor (TLR) stimulation [63]. As SE might activate NK cells directly through TLRs [63-65], more intraepithelial NK cells as well as enhanced activation, such as cytotoxicity and IFN $\gamma$ production, may increase the resistance of chickens against SE infection. IFN $\gamma$ has been reported to activate macrophages resulting in improved clearance of engulfed bacteria [66] and enhanced antigen presentation by APCs inducing $T$ cell responses [67]. Although we were unable to demonstrate a direct relation between NK cell activation and SE counts in the first week post-infection, we hypothesize that NK cells play an important role in the resistance against SE infection. This can be either via direct killing of infected cells or indirectly by influencing

\footnotetext{
(See figure on next page.)

Figure 5 Activation marker expression by splenic APC subsets upon SE infection. A Macrophages, B FSClow DCs and C FSChigh DCS were assessed over time for CHIR-AB1, D-F CD40, G-I CD80 and J-L MHC-Il expression in uninfected (uninf) and SE-infected (SE-inf) chickens. For CHIR-AB1, CD40 and CD80, the percentage of cells in each APC subset expressing the respective markers is shown, and for MHC-II the geometric mean fluorescent intensity (gMFI) of each subset, in accordance with the gating strategy depicted in Additional file 5. Mean + SEM per treatment and time point is shown $(n=5)$, for uninfected chickens at $0 \mathrm{dpi} n=3$ and at $7 \mathrm{dpi} n=4$. Statistical significance is indicated as $*^{*} p<0.05$, ** $p<0.01$, ${ }^{* * * *} p<0.0001$.
} 


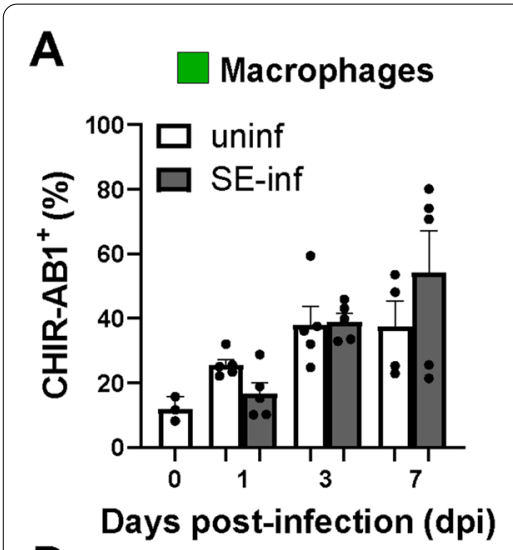

D

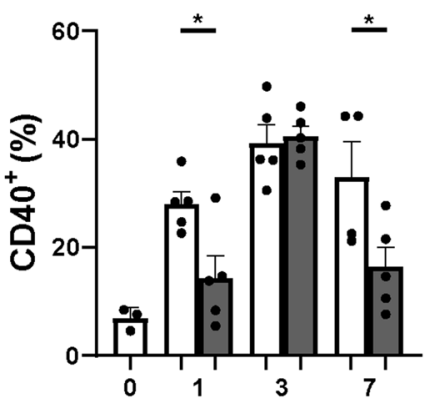

G
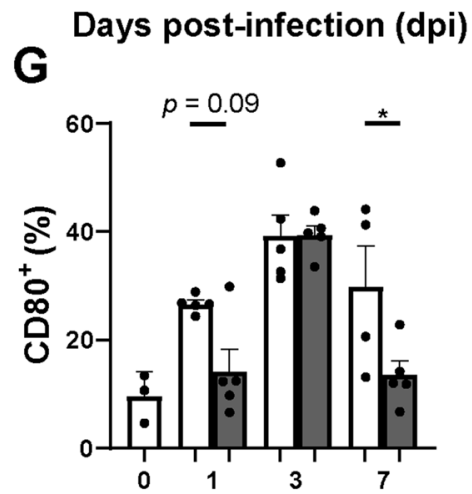

Days post-infection (dpi)

J

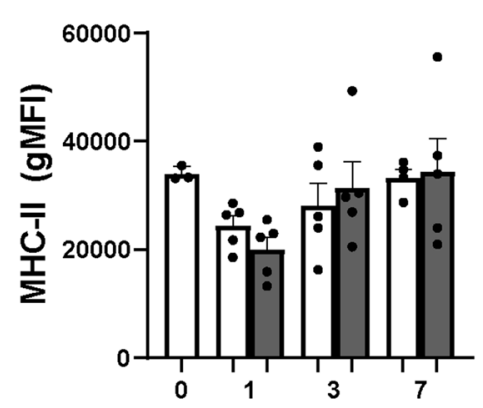

Days post-infection (dpi)

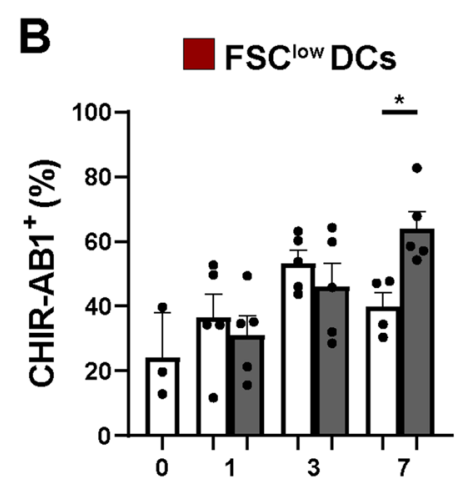

Days post-infection (dpi)

E

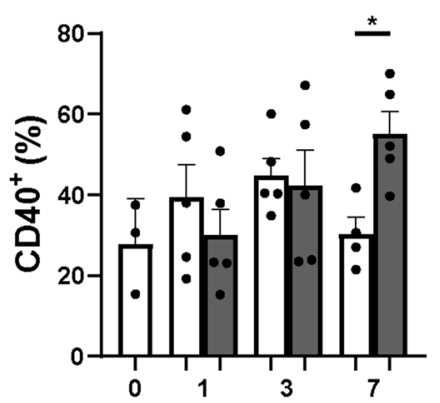

Days post-infection (dpi) $H$

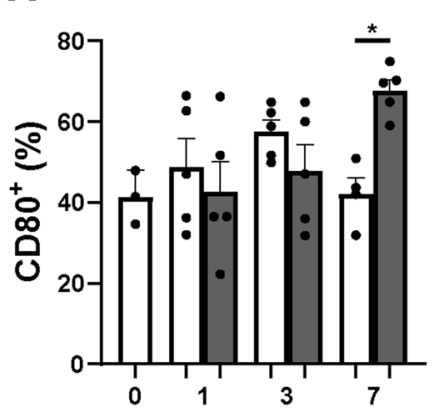

Days post-infection (dpi)

K

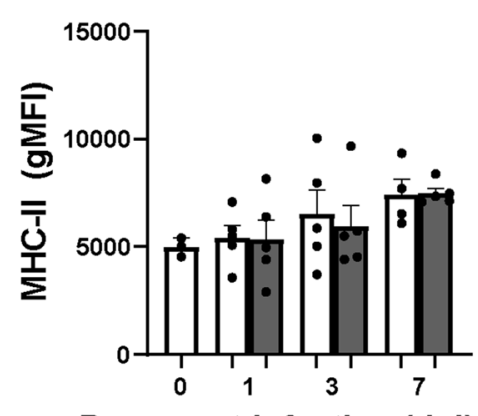

Days post-infection (dpi)

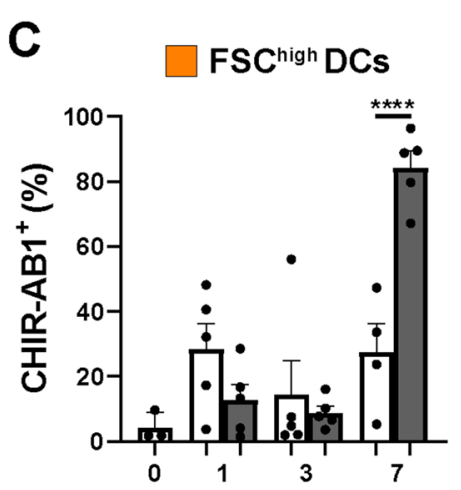

F
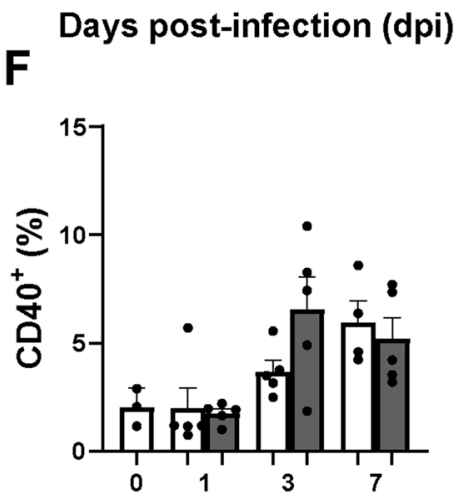

Days post-infection (dpi)

I

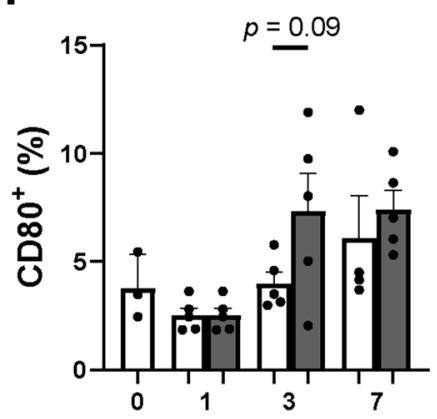

Days post-infection (dpi)

L

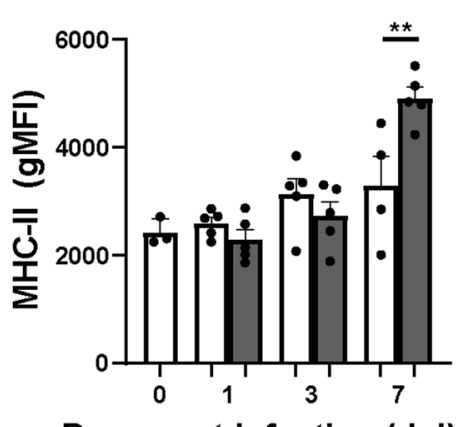

Days post-infection (dpi) 
A

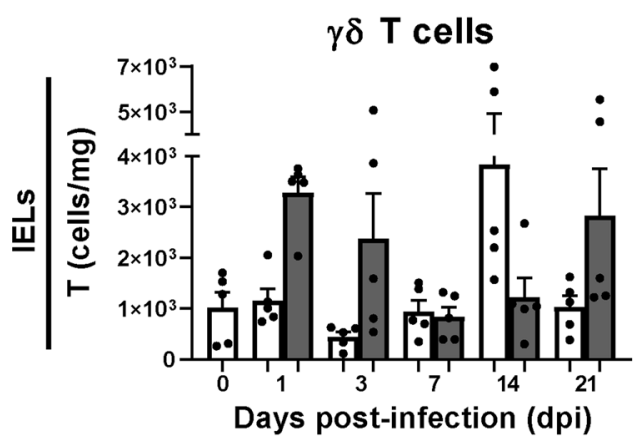

C

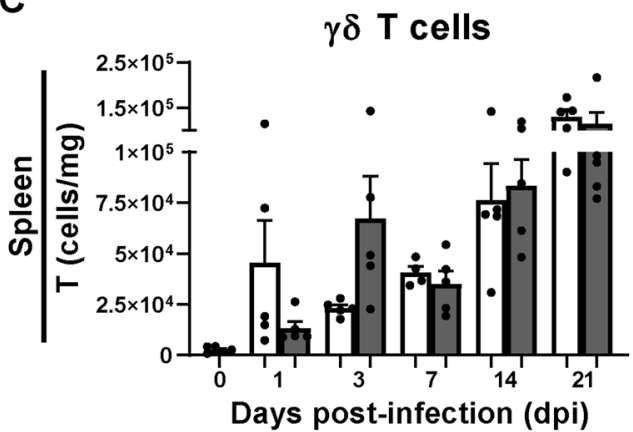

B

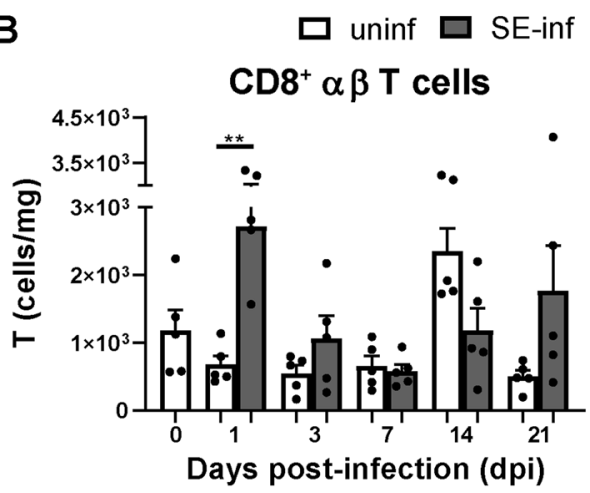

D

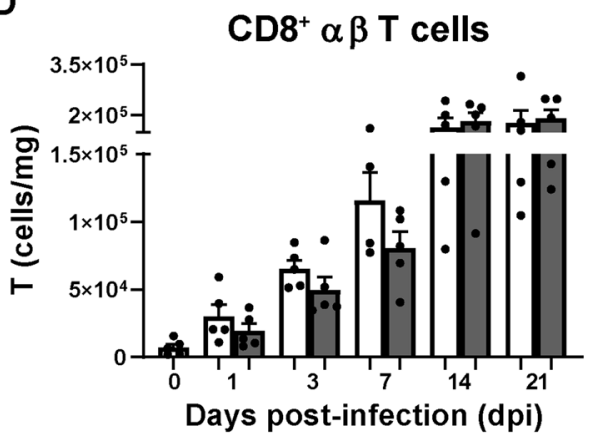

Figure 6 Numbers of intraepithelial and splenic T cells in broiler chickens upon SE infection. A Numbers (cells/mg) of intraepithelial $\gamma \delta T$ cells and $\mathbf{B} C D 8^{+} a \beta$ T cells per mg ileum in uninfected (uninf) and SE-infected (SE-inf) chickens. C Numbers (cells/mg) of splenic $\gamma \delta$ T cells and $\mathbf{D}$ $\mathrm{CD}^{+} \mathrm{a} \beta \mathrm{T}$ cells per mg spleen in uninfected and SE-infected chickens. Mean + SEM per treatment and time point is shown $(n=5)$, for uninfected chickens at $7 \mathrm{dpi}$ in spleen $n=4$. Statistical significance is indicated as ${ }^{* *} p<0.01$.

other innate and adaptive immune cells via the production of IFNY.

The systemic spread of SE infection as observed, coincided with a significantly increased presence of $\mathrm{CD} 11^{+}$ $\mathrm{MRC1LB}^{+}$macrophages in the spleen at $7 \mathrm{dpi}$ when bacterial counts were highest. Previous studies have shown that $\mathrm{MRC}_{1} \mathrm{LB}^{+}$macrophages are largely present in peri-ellipsoid lymphocyte sheaths of the spleen [68], and have a role in clearing blood-borne bacteria in chickens [69], equivalent to that of the marginal zone macrophages in mammals [70]. Therefore, these macrophages are suggested to be involved in clearing the SE from $7 \mathrm{dpi}$ onwards. Expression levels of MHC-II found on $\mathrm{MRC} \mathrm{LB}^{+}$macrophages were higher than those found on the DC subpopulations, which was a surprising finding. In a recent publication, similarly high MHCII expression levels were observed for chicken splenic $\mathrm{MRC1LB}^{+}$macrophages but this level of MHC-II expression was also found on DCs [71]. The FSC ${ }^{\text {high }}$ DCs were numerically higher in presence and showed significant increased expression of CHIR-AB1 and MHC-II at 7 dpi in SE-infected chickens compared to uninfected chickens, indicating a role in antigen presentation. The $\mathrm{FSC}^{\text {low }}$ DCs did not increase in numbers but showed a significant increased expression of the activation markers CHIRAB1, CD40 and CD80 in SE-infected chickens. The two DC subsets were highly similar, and might comprise DCs at different stages of maturation with the $\mathrm{FSC}^{\text {low }}$ subset being more mature based on the expression of CD40, CD80 and MHCII [31, 58, 72]. These results suggest that the increased presence of macrophages clear bacteria initially and the increased activation of DC subsets contribute to antigen presentation to stimulate the adaptive immune responses, all together resulting in further reduction of SE in infected chickens.

Whereas the APC subsets are likely to contribute to the clearance of the bacteria, it has also been suggested that they may worsen the impact of infection by acting as a carrier for Salmonellae [32] and contribute to systemic dissemination [37], since this bacterium is able to survive intracellularly in chicken macrophages $[35,36]$ and DCs [72]. It would be interesting for future studies to determine whether SE can be detected by qPCR in splenic APCs. The ability of Salmonellae to inhibit activation of APCs might explain why NK cells showed earlier activation than APCs and the high presence of SE found at 7 dpi in our study. Other studies have demonstrated that Salmonella-infected APCs secrete IL-12/IL-18 resulting 


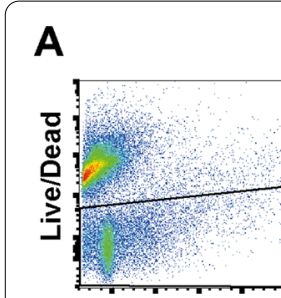

FSC-A

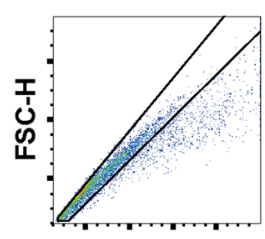

FSC-A

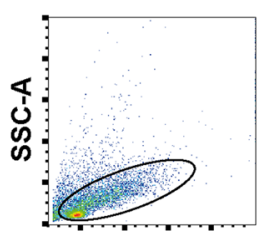

FSC-A

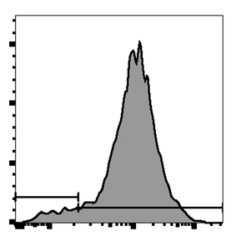

CD3

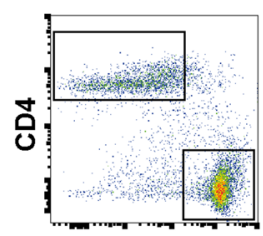

CD8

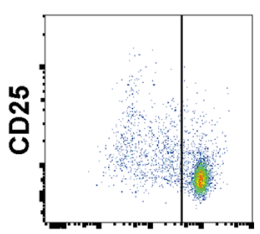

CTV
B

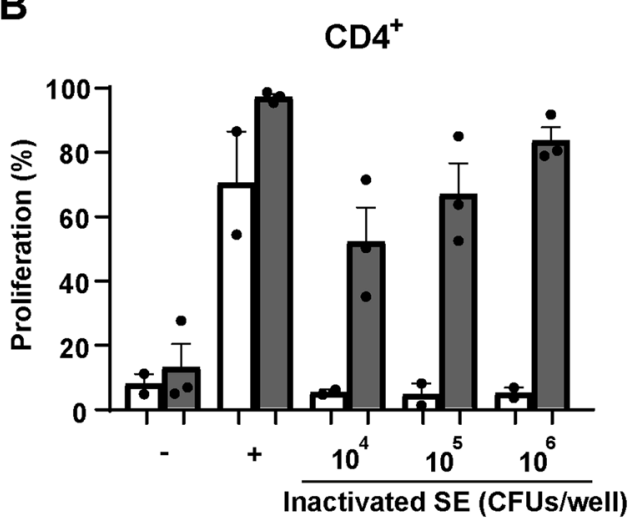

C

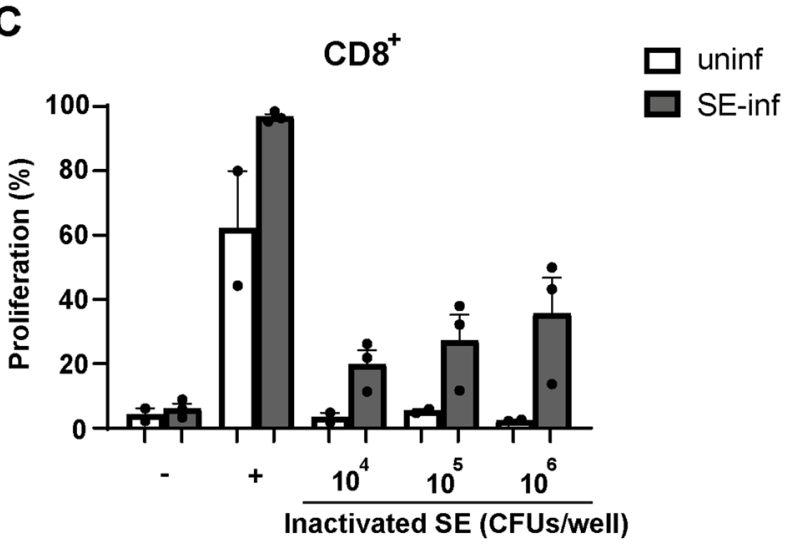

Figure 7 Ex vivo proliferation of SE-induced splenic $\mathrm{CD}^{+}$and $\mathrm{CD}^{+} \mathrm{T}$ cells. A The gating strategy shows the consecutive selection for viable cells (Live/Dead marker-negative), single cells (FSC-A vs FSC-H), lymphocytes (FSC-A vs SSC-A) and CD3 ${ }^{+}$T cells. T cells were subdivided into CD4 ${ }^{+}$ and $C D 8^{+} T$ cells. The final gating step selects on T cell subsets which have divided at least once based on dilution of the cell proliferation dye CellTrace Violet (CTV). B The percentage of cells that have proliferated is shown for splenic CD4 ${ }^{+}$and $\mathbf{C} C D 8^{+}$T cells after 4 days of stimulation with different doses of formaldehyde-inactivated SE expressed in CFU/well, none stimulated controls (-), or after stimulation with anti-CD3, anti-CD28 and recombinant chicken IL-2 (+). All splenocyte samples were stimulated and measured in triplicate for each of the conditions. Mean + SEM is shown; $n=2$ for uninfected (uninf) and $n=3$ for SE-infected (SE-inf) chickens.

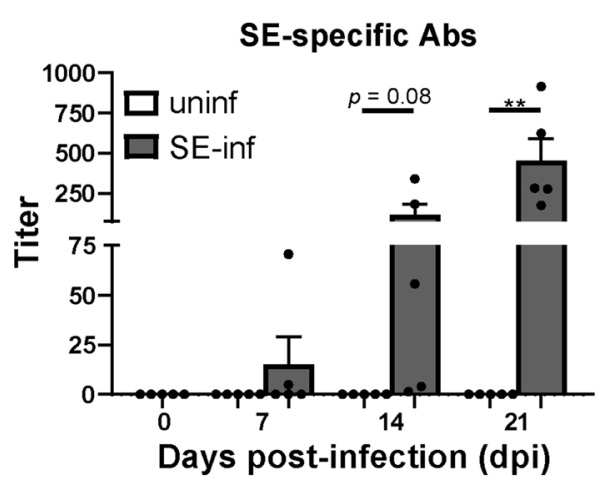

Figure 8 Serum antibody titers in broiler chickens as a response to SE infection. Titers of SE-specific antibodies in sera of uninfected (uninf) and SE-infected (SE-inf) chickens in course of time. Mean + SEM per treatment and time point is shown $(n=5)$ and statistical significance is indicated as ${ }^{* *} p<0.01$.

in enhanced expression of the early activation marker IL-2R $\alpha^{+}$on NK cells, thereby inducing their activation by increased cytotoxicity and IFN $\gamma$ production [24]. This
IFN $\gamma$ production can subsequently stimulate additional macrophages to clear phagocytosed bacteria [73] or impair intracellular survival by direct killing of infectedmacrophages [24], which might be involved in the reduction of SE towards and after $7 \mathrm{dpi}$ observed in our study.

$\mathrm{T}$ cell presence, $\mathrm{SE}$-induced T cell proliferation and SE specific antibodies were addressed as well. All infected chickens in our study had circulating antibodies specific for SE after 3 weeks, which was in agreement with other studies [40, 41]. The observed $\mathrm{T}$ cell responses are similar to increased numbers of intestinal and splenic $\gamma \delta$ and cytotoxic $\alpha \beta$ T cells in response to SE early and 3 weeks after infection [20,26,27], as well as to increased $\mathrm{CD} 8 \alpha \alpha^{+} \gamma \delta \mathrm{T}$ cell numbers $[22,74]$ in prior studies in chickens. The significant increase in cytotoxic CD8 $\alpha \alpha^{+}$ $\mathrm{T}$ cell numbers, however, has not been shown before in chickens in response to SE infection. The more innatelike nature of $\gamma \delta \mathrm{T}$ cell responses early after infection have been recognized as well as the antigen-specific responses of cytotoxic $\mathrm{CD}^{+} \mathrm{T}$ cells approximately 2 weeks after infection, whereas the functional difference between $C D 8 \alpha \alpha$ and $C D 8 \alpha \beta$ expression is less clear 
[75-78]. Although expression of CD107 and IFNY production by intraepithelial and splenic $\gamma \delta$ T cells, cytotoxic $\mathrm{CD}^{+} \mathrm{T}$ cells, and splenic helper $\mathrm{CD} 4^{+} \mathrm{T}$ cells did not significantly differ between uninfected and SE-infected chickens, proliferation of SE-induced splenic T cells of SE-infected chickens ex vivo was observed 3 weeks after infection and not in uninfected chickens. Although the effect of the initial increased presence of $\mathrm{T}$ cells on the numbers of SE in the first week post-infection could not be determined, the SE-specific T cells and antibodies in course of infection are suggested to reduce the number of SE.

In conclusion, this study shows that Salmonella enterica serotype Enteritidis infection in young broiler chickens firstly induces local and systemic activation of NK cells $(1,3,7 \mathrm{dpi})$ as well as presence of intraepithelial $\mathrm{T}$ cells ( $1 \mathrm{dpi})$, followed by increased presence of macrophages and activation of DCs (7 dpi). Subsequently, proliferation of $\mathrm{T}$ cells in the spleen and antibody responses in serum $(21 \mathrm{dpi})$ are induced, all together paralleled by a reduction in SE counts. These insights in understanding the role of NK cell and APC subsets and responses of adaptive immune cells upon SE infection will aid in developing immune-modulation strategies to stimulate innate cells. The potential strengthening of immune responsiveness by vaccines or feed strategies during early life may increase resistance and may prevent SE infection and colonization in young broiler chickens.

\section{Abbreviations \\ SE: Salmonella enterica Serotype Enteritidis; NK cell: Natural killer cell; IELs: Intraepithelial lymphocytes; TCR: T cell receptor; DC: Dendritic cell; APC: Antigen-presenting cell; MRC1LB: Mannose receptor C-type 1-like B; dpi: Day(s) post-infection; ED: Embryonic day; CFU: Colony-forming unit; LOD: Limit of detection; RT: Room temperature; gMFI: Geometric mean fluorescent intensity; FACS: Fluorescence-activated cell sorting; CTV: CellTrace Violet; uninf: Uninfected; SE-inf: SE-infected.}

\section{Supplementary Information}

The online version contains supplementary material available at https://doi. org/10.1186/s13567-021-00978-y.

Additional file 1. Gating strategy of IELs and splenic lymphocytes in broiler chickens. Gating strategy included consecutive selection for lymphocytes (FSC-A vs SSC-A), singlets (FSC-A vs FSC-H) and viable cells (Live) Dead marker-negative) followed by selection of NK and T cell subsets in ileum and spleen. Furthermore, activation of NK and T cells was analyzed by surface expression of CD107 and intracellular expression of IFNy. Conjugate controls are shown for IELs and splenic lymphocytes.

Additional file 2. Effect of SE infection on numbers of splenic NK cells in broiler chickens. A Numbers (cells/mg) of splenic IL-2Ra ${ }^{+}$and B 20E5 ${ }^{+}$NK cells per mg spleen in uninfected (uninf) and SE-infected (SE-inf) chickens in the course of time. $\mathbf{C}$ Gene expression levels of NK cell lineage marker (NFIL3), IL-7Ra and perforin 1 (PRF1) by RT-qPCR in sorted IL-2Ra ${ }^{+}$and $20 \mathrm{E} 5^{+}$NK cell subsets. Mean + SEM per treatment and time point is shown $(n=5)$, for uninfected chickens at $7 \mathrm{dpi} n=4$ and for gene expression levels $n=1$.
Additional file 3 . Staining and sorting controls associated with Figure 4. A The staining controls for the gating strategy are shown. The left panel depicts splenocytes without the viability dye. The middle and right panels show splenocytes that are gated according to Figure 4A, but without the primary antibodies that bind MRC1LB and CD11, respectively. B The graphs show the gating strategy and purity of a representative sample of splenocytes that was sorted into $\mathrm{CD} 11^{+} \mathrm{MRC} 1 \mathrm{LB}^{+}, \mathrm{CD} 11^{+}$ MRC1 1LB ${ }^{-} \mathrm{FSC}^{\text {low }}$ and $\mathrm{CD} 11^{+} \mathrm{MRC}^{\mathrm{L}} \mathrm{LB}^{-} \mathrm{FSC}^{\text {high }}$ subpopulations. The splenocytes that are gated as $\mathrm{CD} 11^{+} \mathrm{MRC} 1 \mathrm{LB}^{-}$in the upper panels are shown in the lower panels to visualize their FSC-A vs SSC-A pattern. $C$ The absolute numbers of sorted APC subpopulations are shown.

Additional file 4. Phenotypic characterization of splenic APCs upon SE infection. A-B The presence (\%) and C-D numbers (cells/mg spleen) of FSC ${ }^{\text {low }}$ DCs and and FSC high DCs in uninfected (uninf) and SE-infected (SE-inf) chickens were assessed over time. Mean + SEM per treatment and time point is shown $(n=5)$, for uninfected chickens at 0 dpi $n=3$ and at 7 dpi $n=4$. Statistical significance is indicated as ${ }^{* *} p<0.01$.

Additional file 5. The gating strategy used to determine the activation status of the APC subsets as depicted in Figure 5. The three identified splenic APC subsets $\mathbf{A}$ macrophages, $\mathbf{B}$ FSC ${ }^{\text {low }}$ DCs and $\mathbf{C}$ FSChigh DCs were assessed for CHIR-AB1, CD40, CD80 and MHC-II. For CHIR-AB1, CD40 and CD80, the cells expressing the respective markers were selected and expressed as a percentage. The expression of MHC-II by each subset was expressed as the geometric mean fluorescent intensity (gMFl).

Additional file 6. Numbers of intraepithelial and splenic $\gamma \delta$ T cells and cytotoxic T cells expressing either CD8aa or CD8a $\beta$ in broiler chickens upon SE infection. A Numbers (cells/mg) of intraepithelial $\mathrm{CD}_{\mathrm{Caa}}{ }^{+} \gamma \delta \mathrm{T}$ cells, $\mathbf{B}$ CD8a $\beta^{+} \gamma \delta \mathrm{T}$ cells, $\mathbf{C}$ cytotoxic CD8aa ${ }^{+} \mathrm{T}$ cells and $\mathbf{D}$ $\mathrm{CD}_{\mathrm{a}} \mathrm{\beta}^{+} \mathrm{T}$ cells per $\mathrm{mg}$ ileum in uninfected (uninf) and SE-infected (SE-inf) chickens in the course of time. $\mathbf{E}$ Numbers (cells/mg) of splenic CD8aa ${ }^{+}$ $\gamma \delta \mathrm{T}$ cells, $\mathbf{F} \mathrm{CD}_{\mathrm{a} a \beta^{+}} \gamma \delta \mathrm{T}$ cells, $\mathbf{G}$ cytotoxic CD8aa ${ }^{+} \mathrm{T}$ cells and $\mathbf{H} \mathrm{CD} 8 \mathrm{a} \beta^{+}$ T cells per $\mathrm{mg}$ spleen in uninfected and SE-infected chickens. Mean + SEM per treatment and time point is shown $(n=5)$, for uninfected chickens at $1 \mathrm{dpi}$ in the IELs and spleen $n=4$ due to numbers of events acquired in the gate of interest were $<100$, and at $7 \mathrm{dpi}$ in spleen $n=4$. Statistical significance is indicated as * $p<0.05,{ }^{* *} p<0.01$. ${ }^{* *} p<0.001$.

Additional file 7. Numbers of $\mathrm{CD4}^{+} \mathrm{T}$ cells in the spleen of broiler chickens upon SE infection. Numbers (cells/mg) of splenic $\mathrm{CD}^{+} \mathrm{a}$ a T cells per mg spleen in uninfected (uninf) and SE-infected (SE-inf) chickens in the course of time. Mean + SEM per treatment and time point is shown $(n=5)$, for uninfected chickens at $7 \mathrm{dpi} n=4$.

Additional file 8. T cell activation in the IEL population and spleen of broiler chickens upon SE infection. A Percentages of intraepithelial CD8 ${ }^{+} T$ cells expressing CD107 (including both $\gamma \delta$ and $a \beta T$ cells) in uninfected (uninf) and SE-infected (SE-inf) chickens in the course of time. B Percentages of splenic CD8 ${ }^{+}$T cells expressing CD107 (including both $\gamma \delta$ and $a \beta T$ cells), $\mathbf{C ~ C D} 8^{+} \gamma \delta$ T cells expressing IFN $\gamma$, D CD4 ${ }^{+} a \beta T$ cells expressing IFNy and $\mathbf{E} C D 8^{+}$a $\beta$ T cells expressing IFNy in uninfected (uninf) and SE-infected (SE-inf) chickens over time. Mean + SEM per treatment and time point is shown $(n=5)$, for uninfected chickens at 7 dpi in spleen $n=4$ and at 1 and $3 \mathrm{dpi}$ in the IELs percentages were not determined (n.d.) due to numbers of events acquired in the gate of interest were $<100$.

\section{Acknowledgements}

We thank the animal caretakers and F.C. Velkers of the Department Population Health Sciences, division Farm Animal Health, Faculty of Veterinary Medicine, Utrecht University, for their help during the animal experiments and SE inoculation. We acknowledge E. Broens and A.J. Timmerman of the VMDC, Faculty of Veterinary Medicine, Utrecht University, for kindly providing the SE strain and help with the SE culture. We are thankful to I.S. Ludwig for her help during the isolation of immune cells and we acknowledge G.J.A. Arkesteijn for maintaining optimal working conditions of the Flow Cytometry and Cell Sorting Facility, Faculty of Veterinary Medicine, Utrecht University. 


\section{Authors' contributions}

NM, JS, VR and CJ contributed to the conception and design of the study. $\mathrm{NM}, \mathrm{RB}$ and $\mathrm{DH}$ contributed to acquisition of data. NM and RB performed the analysis of data. CJ supervised the work. NM, RB, JS, VR and CJ contributed to drafting and critically revising it for important intellectual content. All authors read and approved the final manuscript.

\section{Funding}

This work is part of the research programme of NWO Earth and Life Sciences (ALW) with project number 868.15.020, which is financed by the Dutch Research Council (NWO) and by Cargill Animal Nutrition and Health. The funders had no role in study design, data collection and analysis, decision to publish, or preparation of the manuscript.

\section{Availability of data and materials}

All data generated or analyzed during this study are included in this published article [and its additional information files].

\section{Declarations}

\section{Ethics approval and consent to participate}

The animal experiment was approved by the Dutch Central Authority for Scientific Procedures on Animals and the Animal Experiments Committee (registration number AVD1080020174425) of Utrecht University (the Netherlands) and all procedures were done in full compliance with all relevant legislation.

\section{Competing interests}

The authors declare that they have no competing interests.

\section{Author details}

${ }^{1}$ Department Biomolecular Health Sciences, Division Infectious Diseases and Immunology, Faculty of Veterinary Medicine, Utrecht University, Utrecht, The Netherlands. ${ }^{2}$ Department Population Health Sciences, Division Farm Animal Health, Faculty of Veterinary Medicine, Utrecht University, Utrecht, The Netherlands. ${ }^{3}$ Department of Veterinary Tropical Diseases, Faculty of Veterinary Science, University of Pretoria, Pretoria, South Africa. ${ }^{4}$ Present Address: Department of Animal Sciences, Cell Biology and Immunology Group, Wageningen University and Research, Wageningen, The Netherlands.

Received: 15 February 2021 Accepted: 15 July 2021

Published online: 17 August 2021

\section{References}

1. Kallapura G, Morgan MJ, Pumford NR, Bielke LR, Wolfenden AD, Faulkner OB, Latorre JD, Menconi A, Hernandez-Velasco X, Kuttappan VA, Hargis BM, Tellez G (2014) Evaluation of the respiratory route as a viable portal of entry for Salmonella in poultry via intratracheal challenge of Salmonella Enteritidis and Salmonella Typhimurium. Poult Sci 93:340-346

2. Kallapura G, Kogut MH, Morgan MJ, Pumford NR, Bielke LR, Wolfenden AD, Faulkner OB, Latorre JD, Menconi A, Hernandez-Velasco X, Kuttappan VA, Hargis BM, Tellez G (2014) Fate of Salmonella Senftenberg in broiler chickens evaluated by challenge experiments. Avian Pathol 43:305-309

3. Suzuki S (1994) Pathogenicity of Salmonella enteritidis in poultry. Int J Food Microbiol 21:89-105

4. World Organisation (2019) Prevention, detection and control of Salmonella in poultry. In: OIE (ed) Terrestrial animal health code. Office International des Epizooties, Paris

5. Sharma JM, Tizard I (1984) Avian cellular immune effector mechanismsa review. Avian Pathol 13:357-376

6. Klasing KC, Leshchinsky T (1999) Functions, costs and benefits of the immune system during development and growth. In: Adams NJ, Slotow $\mathrm{RH}$ (eds) Proceedings of the 22nd international ornithological congress. Birdlife South Africa, Johannesburg. pp 2817-2835

7. Chai J, Lillehoj HS (1988) Isolation and functional characterization of chicken intestinal intra-epithelial lymphocytes showing natural killer cell activity against tumour target cells. Immunology 63:111-117
8. Gómez Del Moral M, Fonfría J, Varas A, Jiménez E, Moreno J, Zapata AG (1998) Appearance and development of lymphoid cells in the chicken (Gallus gallus) caecal tonsil. Anat Rec 250:182-189

9. Simon K, De Vries RG, Kemp B, Lammers A (2014) Development of Ileal cytokine and immunoglobulin expression levels in response to early feeding in broilers and layers. Poult Sci 93:3017-3027

10. Befus AD, Johnston N, Leslie GA, Bienenstock J (1980) Gut-associated lymphoid tissue in the chicken. I. Morphology, ontogeny, and some functional characteristics of Peyer's patches. J Immunol 125:2626-2632

11. Göbel TWF, Kaspers B, Stangassinger M (2001) NK and T cells constitute two major, functionally distinct intestinal epithelial lymphocyte subsets in the chicken. Int Immunol 13:757-762

12. Meijerink N, van Haarlem DA, Velkers FC, Stegeman AJ, Rutten VPMG, Jansen CA (2021) Analysis of chicken intestinal natural killer cells, a major IEL subset during embryonic and early life. Dev Comp Immunol 114:103857

13. Fenzl L, Göbel TW, Neulen M-L (2017) ү $\delta$ T cells represent a major spontaneously cytotoxic cell population in the chicken. Dev Comp Immunol 73:175-183

14. Lillehoj HS, Trout JM (1996) Avian gut-associated lymphoid tissues and intestinal immune responses to Eimeria parasites. Clin Microbiol Rev 9:349-360

15. Schokker D, De Koning D-J, Rebel JMJ, Smits MA (2011) Shift in chicken intestinal gene association networks after infection with Salmonella. Comp Biochem Physiol Part D Genom Proteom 6:339-347

16. Li X, Zhang $P$, Jiang $X$, Du H, Yang C, Zhang Z, Men S, Zhang Z, Jiang W, Wang $H$ (2017) Differences in expression of genes in the MyD88 and TRIF signalling pathways and methylation of TLR4 and TRIF in Tibetan chickens and DaHeng S03 chickens infected with Salmonella enterica serovar enteritidis. Vet Immunol Immunopathol 189:28-35

17. Matulova M, Varmuzova K, Sisak F, Havlickova H, Babak V, Stejskal K, Zdrahal Z, Rychlik I (2013) Chicken innate immune response to oral infection with Salmonella enterica serovar Enteritidis. Vet Res 44:37

18. Swaggerty CL, Kogut MH, Ferro PJ, Rothwell L, Pevzner IY, Kaiser P (2004) Differential cytokine mRNA expression in heterophils isolated from Salmonella-resistant and -susceptible chickens. Immunology 113:139-148

19. Schokker D, Smits MA, Hoekman AJW, Parmentier HK, Rebel JMJ (2010) Effects of Salmonella on spatial-temporal processes of jejunal development in chickens. Dev Comp Immunol 34:1090-1100

20. Carvajal BG, Methner U, Pieper J, Berndt A (2008) Effects of Salmonella enterica serovar Enteritidis on cellular recruitment and cytokine gene expression in caecum of vaccinated chickens. Vaccine 26:5423-5433

21. Sekelova Z, Stepanova H, Polansky O, Varmuzova K, Faldynova M, Fedr R, Rychlik I, Vlasatikova L (2017) Differential protein expression in chicken macrophages and heterophils in vivo following infection with Salmonella Enteritidis. Vet Res 48:35

22. Berndt A, Pieper J, Methner U (2006) Circulating $\gamma \delta$ T cells in response to Salmonella enterica serovar enteritidis exposure in chickens. Infect Immun 74:3967-3978

23. Schafer R, Eisenstein TK (1992) Natural killer cells mediate protection induced by a Salmonella aroA mutant. Infect Immun 60:791-797

24. Lapaque N, Walzer T, Méresse S, Vivier E, Trowsdale J (2009) Interactions between human NK cells and macrophages in response to Salmonella infection. J Immunol 182:4339-4348

25. Harrington L, Srikanth CV, Antony R, Shi HN, Cherayil BJ (2007) A role for natural killer cells in intestinal inflammation caused by infection with Salmonella enterica serovar Typhimurium. FEMS Immunol Med Microbiol 51:372-380

26. Schokker D, Peters THF, Hoekman AJW, Rebel JMJ, Smits MA (2012) Differences in the early response of hatchlings of different chicken breeding lines to Salmonella enterica serovar Enteritidis infection. Poult Sci 91:346-353

27. Van Hemert S, Hoekman AJW, Smits MA, Rebel JMJ (2007) Immunological and gene expression responses to a Salmonella infection in the chicken intestine. Vet Res 38:51-63

28. van Hemert S, Hoekman AJW, Smits MA, Rebel JMJ (2006) Gene expression responses to a Salmonella infection in the chicken intestine differ between lines. Vet Immunol Immunopathol 114:247-258 
29. van Hemert S, Hoekman AJW, Smits MA, Rebel JMJ (2006) Early host gene expression responses to a Salmonella infection in the intestine of chickens with different genetic background examined with cDNA and oligonucleotide microarrays. Comp Biochem Physiol Part D Genom Proteom 1:292-299

30. Staines K, Hunt LG, Young JR, Butter C (2014) Evolution of an expanded mannose receptor gene family. PLoS One 9:e110330

31. Kamble NM, Jawale CV, Lee JH (2016) Activation of chicken bone marrow-derived dendritic cells induced by a Salmonella Enteritidis ghost vaccine candidate. Poult Sci 95:2274-2280

32. Chappell L, Kaiser P, Barrow P, Jones MA, Johnston C, Wigley P (2009) The immunobiology of avian systemic salmonellosis. Vet Immunol Immunopathol 128:53-59

33. Gomes AVS, Quinteiro-Filho WM, Ribeiro A, Ferraz-de-Paula V, Pinheiro ML, Baskeville E, Akamine AT, Astolfi-Ferreira CS, Ferreira AJP, Palermo-Neto J (2014) Overcrowding stress decreases macrophage activity and increases Salmonella Enteritidis invasion in broiler chickens. Avian Pathol 43:82-90

34. Vazquez-Torres A, Xu Y, Jones-Carson J, Holden DW, Lucia SM, Dinauer MC, Mastroeni P, Fang FC (2000) Salmonella pathogenicity island 2-dependent evasion of the phagocyte NADPH oxidase. Science 287:1655-1658

35. Jones MA, Wigley P, Page KL, Hulme SD, Barrow PA (2001) Salmonella enterica serovar Gallinarum requires the Salmonella pathogenicity island 2 type III secretion system but not the Salmonella pathogenicity island 1 type III secretion system for virulence in chickens. Infect Immun 69:5471-5476

36. Jones MA, Hulme SD, Barrow PA, Wigley P (2007) The Salmonella pathogenicity island 1 and Salmonella pathogenicity island 2 type III secretion systems play a major role in pathogenesis of systemic disease and gastrointestinal tract colonization of Salmonella enterica serovar Typhimurium in the chicken. Avian Pathol 36:199-203

37. Vazquez-Terres A, Jones-Carson J, Bäumler AJ, Falkow S, Valdivia R, Brown W, Lo M, Berggren R, Parks WT, Fang FC (1999) Extraintestinal dissemination of Salmonella by CD18-expressing phagocytes. Nature 401:804-808

38. Sekelova Z, Polansky O, Stepanova H, Fedr R, Faldynova M, Rychlik I, Vlasatikova L (2017) Different roles of CD4, CD8 and $\gamma \delta$ T-lymphocytes in naive and vaccinated chickens during Salmonella Enteritidis infection. Proteomics 17:1700073

39. Desmidt M, Ducatelle R, Mast J, Goddeeris BM, Kaspers B, Haesebrouck F (1998) Role of the humoral immune system in Salmonella enteritidis phage type four infection in chickens. Vet Immunol Immunopathol 63:355-367

40. Zhen W, Shao Y, Gong X, Wu Y, Geng Y, Wang Z, Guo Y (2018) Effect of dietary Bacillus coagulans supplementation on growth performance and immune responses of broiler chickens challenged by Salmonella enteritidis. Poult Sci 97:2654-2666

41. Berthelot-Hérault F, Mompart F, Zygmunt MS, Dubray GE, DuchetSuchaux M (2003) Antibody responses in the serum and gut of chicken lines differing in cecal carriage of Salmonella enteritidis. Vet Immunol Immunopathol 96:43-52

42. Meijerink N, Kers JG, Velkers FC, van Haarlem DA, Lamot DM, de Oliveira JE, Smidt H, Stegeman JA, Rutten VPMG, Jansen CA (2020) Early life inoculation with adult-derived microbiota accelerates maturation of intestinal microbiota and enhances NK cell activation in broiler chickens. Front Vet Sci 7:584561

43. Van De Reep L, Nielen M, Verstappen KMHW, Broens EM, Van Den Broek J, Velkers FC (2018) Response to a Salmonella Enteritidis challenge in old laying hens with different vaccination histories. Poult Sci 97:2733-2739

44. Jansen $C A$, van de Haar PM, van Haarlem D, van Kooten $P$, de Wit $S$, van Eden W, Viertlböck BC, Göbel TW, Vervelde L (2010) Identification of new populations of chicken natural killer (NK) cells. Dev Comp Immunol 34:759-767

45. Ariaans MP, van de Haar PM, Lowenthal JW, van Eden W, Hensen EJ, Vervelde L (2008) ELISPOT and intracellular cytokine staining: Novel assays for quantifying $\mathrm{T}$ cell responses in the chicken. Dev Comp Immunol 32:1398-1404

46. Belkina AC, Ciccolella CO, Anno R, Halpert R, Spidlen J, Snyder-Cappione JE (2019) Automated optimized parameters for T-distributed stochastic neighbor embedding improve visualization and analysis of large datasets. Nat Commun 10:5415
47. van den Biggelaar RHGA, van Eden W, Rutten VPMG, Jansen CA (2020) Nitric oxide production and fc receptor-mediated phagocytosis as functional readouts of macrophage activity upon stimulation with inactivated poultry vaccines in vitro. Vaccines 8:332

48. Viertlboeck BC, Schweinsberg S, Hanczaruk MA, Schmitt R, Pasquier LD, Herberg FW, Göbel TW (2007) The chicken leukocyte receptor complex encodes a primordial, activating, high-affinity IgY Fc receptor. Proc Natl Acad Sci U S A 104:11718-11723

49. Eldaghayes I, Rothwell L, Williams A, Withers D, Balu S, Davison F, Kaiser $P(2006)$ Infectious bursal disease virus: Strains that differ in virulence differentially modulate the innate immune response to infection in the chicken bursa. Viral Immunol 19:83-91

50. Michaud A, Dardari R, Charrier E, Cordeiro P, Herblot S, Duval M (2010) IL-7 enhances survival of human CD56bright NK cells. J Immunother 33:382-390

51. Male V, Nisoli I, Kostrzewski T, Allan DS, Carlyle JR, Lord GM, Wack A, Brady HJ (2014) The transcription factor E4bp4/Nfil3 controls commitment to the NK lineage and directly regulates Eomes and Id2 expression. J Exp Med 211:635-642

52. Wendt K, Wilk E, Buyny S, Buer J, Schmidt RE, Jacobs R (2006) Gene and protein characteristics reflect functional diversity of CD56 dim and CD56bright NK cells. J Leukocyte Biol 80:1529-1541

53. Di Santo JP (2009) A defining factor for natural killer cell development. Nat Immunol 10:1051-1052

54. Luevano M, Madrigal A, Saudemont A (2012) Transcription factors involved in the regulation of natural killer cell development and function: an update. Front Immunol 3:319

55. Sarson AJ, Abdul-Careem MF, Read LR, Brisbin JT, Sharif S (2008) Expression of cytotoxicity-associated genes in Marek's disease virus-infected chickens. Viral Immunol 21:267-272

56. Livak KJ, Schmittgen TD (2001) Analysis of relative gene expression data using real-time quantitative $P C R$ and the $2-\triangle \triangle C T$ method. Methods 25:402-408

57. Manh T-V, Marty H, Sibille P, Vern YL, Kaspers B, Dalod M, Schwartz-Cornil I, Quéréx P (2014) Existence of conventional dendritic cells in Gallus gallus revealed by comparative gene expression profiling. J Immunol 192:4510-4517

58. van den Biggelaar RHGA, Arkesteijn GJA, Rutten VPMG, van Eden W, Jansen CA (2020) In vitro chicken bone marrow-derived dendritic cells comprise subsets at different states of maturation. Front Immunol 11:141

59. Sundick RS, Gill-Dixon C (1997) A cloned chicken lymphokine homologous to both mammalian IL-2 and IL-15. J Immunol 159:720-725

60. Raehtz S, Hargis BM, Kuttappan VA, Pamukcu R, Bielke LR, McCabe LR (2018) High molecular weight polymer promotes bone health and prevents bone loss under salmonella challenge in broiler chickens. Front Physiol 9:384

61. Khan MI, Fadl AA, Venkitanarayanan KS (2003) Reducing colonization of Salmonella Enteritidis in chicken by targeting outer membrane proteins. J Appl Microbiol 95:142-145

62. Gast RK, Regmi P, Guraya R, Jones DR, Anderson KE, Karcher DM (2019) Colonization of internal organs by Salmonella Enteritidis in experimentally infected laying hens of four commercial genetic lines in conventional cages and enriched colony housing. Poult Sci 98:1785-1790

63. Rudnicka K, Matusiak A, Chmiela M (2015) CD25 (IL-2R) expression correlates with the target cell induced cytotoxic activity and cytokine secretion in human natural killer cells. Acta Biochim Pol 62:885-894

64. Adib-Conquy M, Scott-Algara D, Cavaillon J-M, Souza-Fonseca-Guimaraes F (2014) TLR-mediated activation of NK cells and their role in bacterial/ viral immune responses in mammals. Immunol Cell Biol 92:256-262

65. Marcenaro E, Ferranti B, Falco M, Moretta L, Moretta A (2008) Human NK cells directly recognize Mycobacterium bovis via TLR2 and acquire the ability to kill monocyte-derived DC. Int Immunol 20:1155-1167

66. Okamura M, Lillehoj HS, Raybourne RB, Babu US, Heckert RA, Tani H, Sasai K, Baba E, Lillehoj EP (2005) Differential responses of macrophages to Salmonella enterica serovars Enteritidis and Typhimurium. Vet Immunol Immunopathol 107:327-335

67. Pallmer K, Oxenius A (2016) Recognition and regulation of T cells by NK cells. Front Immunol 7:251

68. Hu T, Wu Z, Bush SJ, Freem L, Vervelde L, Summers KM, Hume DA, Balic A, Kaiser P (2019) Characterization of subpopulations of chicken 
mononuclear phagocytes that express TIM4 and CSF1R. J Immunol 202:1186-1199

69. Yu K, Gu MJ, Pyung YJ, Song K, Park TS, Han SH, Yun C (2020) Characterization of splenic MRC1 (hi)MHCII(lo) and MRC1 (lo)MHCll(hi) cells from the monocyte/macrophage lineage of White Leghorn chickens. Vet Res 51:73

70. A-Gonzalez N, Guillen JA, Gallardo G, Diaz M, De La Rosa JV, Hernandez IH, Casanova-Acebes M, Lopez F, Tabraue C, Beceiro S, Hong C, Lara PC, Andujar M, Arai S, Miyazaki T, Li S, Corbi AL, Tontonoz P, Hidalgo A, Castrillo A (2013) The nuclear receptor LXRa controls the functional specialization of splenic macrophages. Nat Immunol 14:831-839

71. Sutton KM, Morris KM, Borowska D, Sang H, Kaiser P, Balic A, Vervelde L (2021) Characterization of conventional dendritic cells and macrophages in the spleen using the CSF1R-reporter transgenic chickens. Front Immunol 12:528

72. Kamble NM, Jawale CV, Lee JH (2016) Interaction of a live attenuated Salmonella Gallinarum vaccine candidate with chicken bone marrowderived dendritic cells. Avian Pathol 45:235-243

73. Rosenberger CM, Brett Finlay B (2002) Macrophages inhibit Salmonella Typhimurium replication through MEK/ERK kinase and phagocyte NADPH oxidase activities. J Biol Chem 277:18753-18762

74. Pieper J, Methner U, Berndt A (2011) Characterization of avian $\gamma \delta$ T-cell subsets after Salmonella enterica serovar typhimurium infection of chicks. Infect Immun 79:822-829
75. Gangadharan D, Cheroutre $H$ (2004) The CD8 isoform CD8aa is not a functional homologue of the TCR co-receptor CD8aß. Curr Opin Immunol 16:264-270

76. Cheroutre H, Lambolez F, Mucida D (2011) The light and dark sides of intestinal intraepithelial lymphocytes. Nat Rev Immunol 11:445-456

77. Pasman L, Kasper DL (2017) Building conventions for unconventional lymphocytes. Immunol Rev 279:52-62

78. Leishman AJ, Naidenko OV, Attinger A, Koning F, Lena CJ, Xiong Y, Chang H, Reinherz E, Kronenberg M, Cheroutre H (2001) T cell responses modulated through interaction between CD8aa and the nonclassical MHC class I molecule, TL. Science 294:1936-1939

79. van Haarlem DA, van Kooten PJS, Rothwell L, Kaiser P, Vervelde L (2009) Characterisation and expression analysis of the chicken interleukin-7 receptor alpha chain. Dev Comp Immunol 33:1018-1026

\section{Publisher's Note}

Springer Nature remains neutral with regard to jurisdictional claims in published maps and institutional affiliations.
Ready to submit your research? Choose BMC and benefit from:

- fast, convenient online submission

- thorough peer review by experienced researchers in your field

- rapid publication on acceptance

- support for research data, including large and complex data types

- gold Open Access which fosters wider collaboration and increased citations

- maximum visibility for your research: over $100 \mathrm{M}$ website views per year

At BMC, research is always in progress.

Learn more biomedcentral.com/submissions 